\title{
Online Appendix for: When the Floodgates Open: "Northern" Firms' Response to Removal of Trade Quotas on Chinese Goods
}

\author{
Hale Utar
}

\section{A Additional Analysis}

Table A-1: T\&C Exports

\begin{tabular}{|c|c|c|}
\hline \multirow[t]{2}{*}{ Sample } & \multicolumn{2}{|c|}{ Textile and Apparel Products } \\
\hline & (a) & (b) \\
\hline Variables & Log Price & Log Value \\
\hline \multirow[t]{2}{*}{ Dum02 * MFAQ2 $2_{j}$} & $-0.135^{* *}$ & -0.171 \\
\hline & $(0.045)$ & $(0.108)$ \\
\hline \multirow{2}{*}{$D u m 05 * M F A Q 5_{j}$} & -0.052 & $-0.340 * * *$ \\
\hline & $(0.043)$ & $(0.093)$ \\
\hline Year By Industry Fixed Effect & yes & yes \\
\hline Product (CN8) Fixed Effect & yes & yes \\
\hline Number of Obs. & 14387 & 14387 \\
\hline Number of (CN8) Products & 1583 & 1583 \\
\hline $\mathrm{F}$ & 3.606 & 7.865 \\
\hline
\end{tabular}


Table A-2: Production Fragmentation, Productivity, Capital Per Labor

\begin{tabular}{|c|c|c|c|c|}
\hline Sample & $\begin{array}{l}\text { Textile and Ap } \\
\text { (a) } \\
\text { Fragmentation } \\
\text { Measure }\end{array}$ & $\begin{array}{l}\text { arel Manuf } \\
\text { (b) } \\
\text { Empirical } \\
\text { Markup }\end{array}$ & $\begin{array}{l}\text { urers 1995-2007 } \\
\text { (c) } \\
\text { Labor } \\
\text { Productivity }\end{array}$ & $\begin{array}{l}(\mathrm{d}) \\
\text { Log Capital } \\
\text { per Labor }\end{array}$ \\
\hline \multicolumn{5}{|l|}{ Panel A } \\
\hline MFAQProd $99_{i} *$ Dum $02_{t}$ & $\begin{array}{l}-0.019 \\
(0.060)\end{array}$ & $\begin{array}{l}-0.019 \\
(0.045)\end{array}$ & $\begin{array}{c}0.097^{* *} \\
(0.036)\end{array}$ & $\begin{array}{l}0.225^{* *} \\
(0.084)\end{array}$ \\
\hline $\mathrm{F}$ & 19.471 & 17.977 & 15.739 & 16.035 \\
\hline \multicolumn{5}{|l|}{ Panel B } \\
\hline MF AQProdShare $99_{i} *$ Dum $02_{t}$ & $\begin{array}{c}-0.215^{* *} \\
(0.066)\end{array}$ & $\begin{array}{l}-0.114 \\
(0.088)\end{array}$ & $\begin{array}{c}0.198^{* *} \\
(0.066)\end{array}$ & $\begin{array}{l}0.376^{*} \\
(0.149)\end{array}$ \\
\hline $\mathrm{F}$ & 21.085 & 17.992 & 15.842 & 15.917 \\
\hline \multicolumn{5}{|l|}{ Panel C } \\
\hline MFAQRevShare $99_{i} *{\text { Dum } 02_{t}}_{1}$ & $\begin{array}{c}-0.172^{* *} \\
(0.058)\end{array}$ & $\begin{array}{l}-0.084 \\
(0.073)\end{array}$ & $\begin{array}{l}0.122^{*} \\
(0.052)\end{array}$ & $\begin{array}{c}0.201 \\
(0.123)\end{array}$ \\
\hline $\mathrm{F}$ & 20.560 & 17.973 & 15.743 & 15.816 \\
\hline Year Fixed Effects & yes & yes & yes & yes \\
\hline Firm Fixed Effects & yes & yes & yes & yes \\
\hline Number of Obs. & 7247 & 7078 & 7212 & 7054 \\
\hline Number of Firms & 1093 & 1087 & 1093 & 1083 \\
\hline
\end{tabular}

Robust standard errors are reported in parentheses. They are clustered for firms. A constant term is included but not reported. ${ }^{*},{ }^{*}$ and ${ }^{* * *}$ indicate significance at the $10 \%, 5 \%$ and $1 \%$ levels respectively. Fixed effect indicators and sample information reported at the bottom of the table corresponds to all regressions across panels in each column. The dependent variable in column $\mathrm{a}$ is the logit transformation of value added divided by the gross value of output. The dependent variable in column $\mathrm{b}$ is the logit transformation of value added minus labor costs over the gross value of output. The dependent variable in column $\mathrm{c}$ is the logarithm of the sales over the full-time unit of employment. The dependent variable in column $\mathrm{d}$ is the logarithm of the physical capital per full-time equivalent labor. Source: Statistics Denmark. 


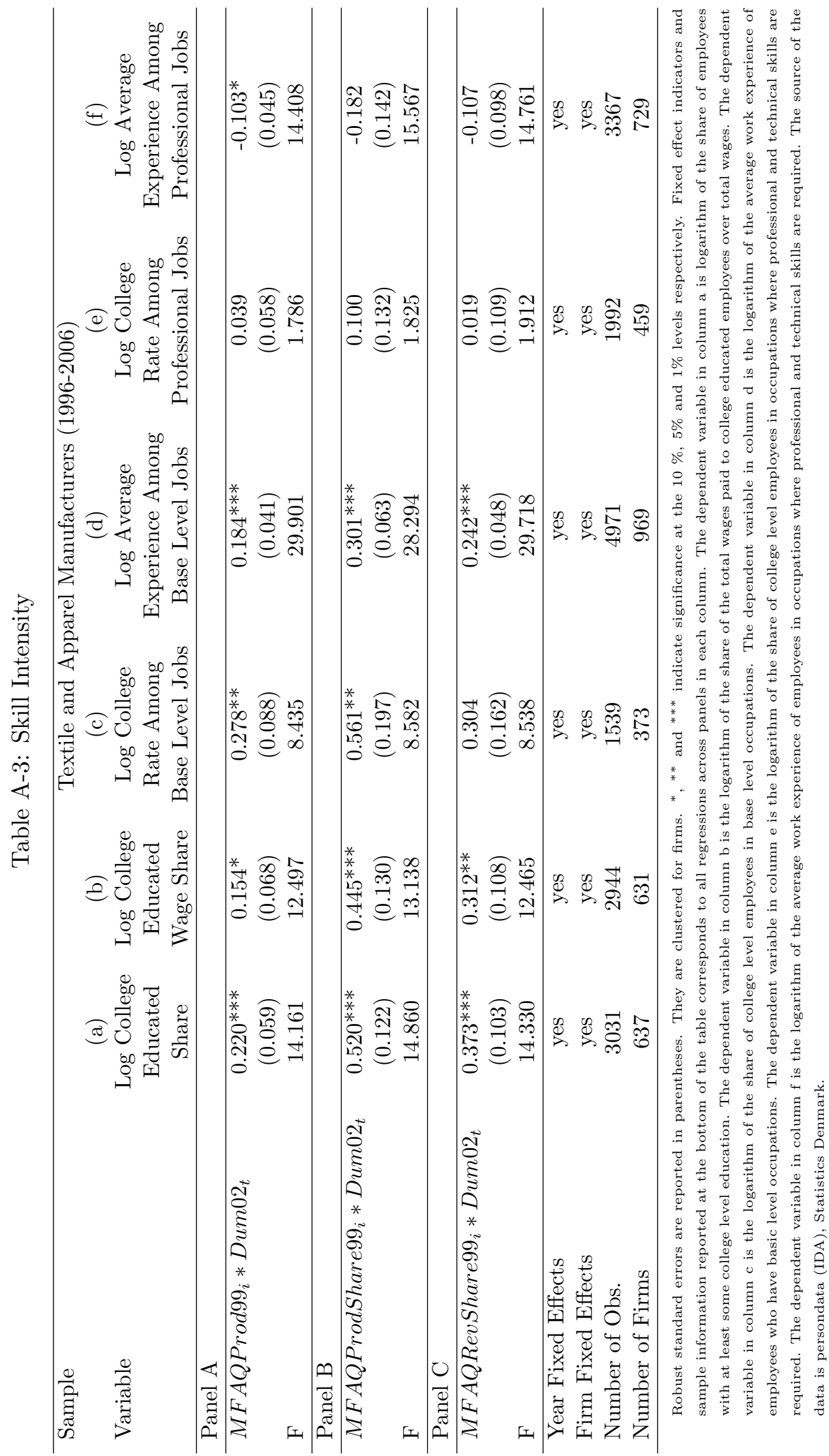




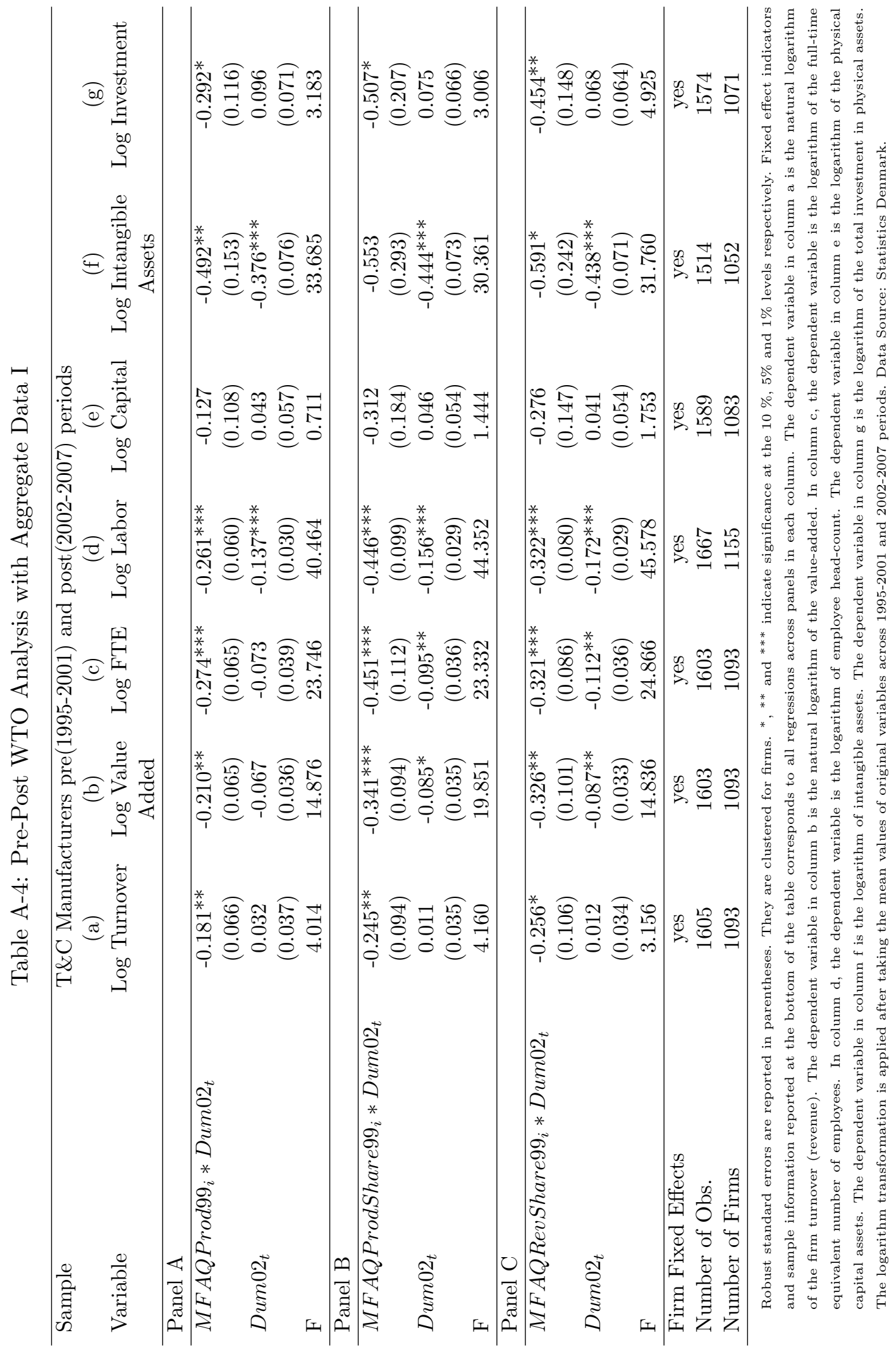




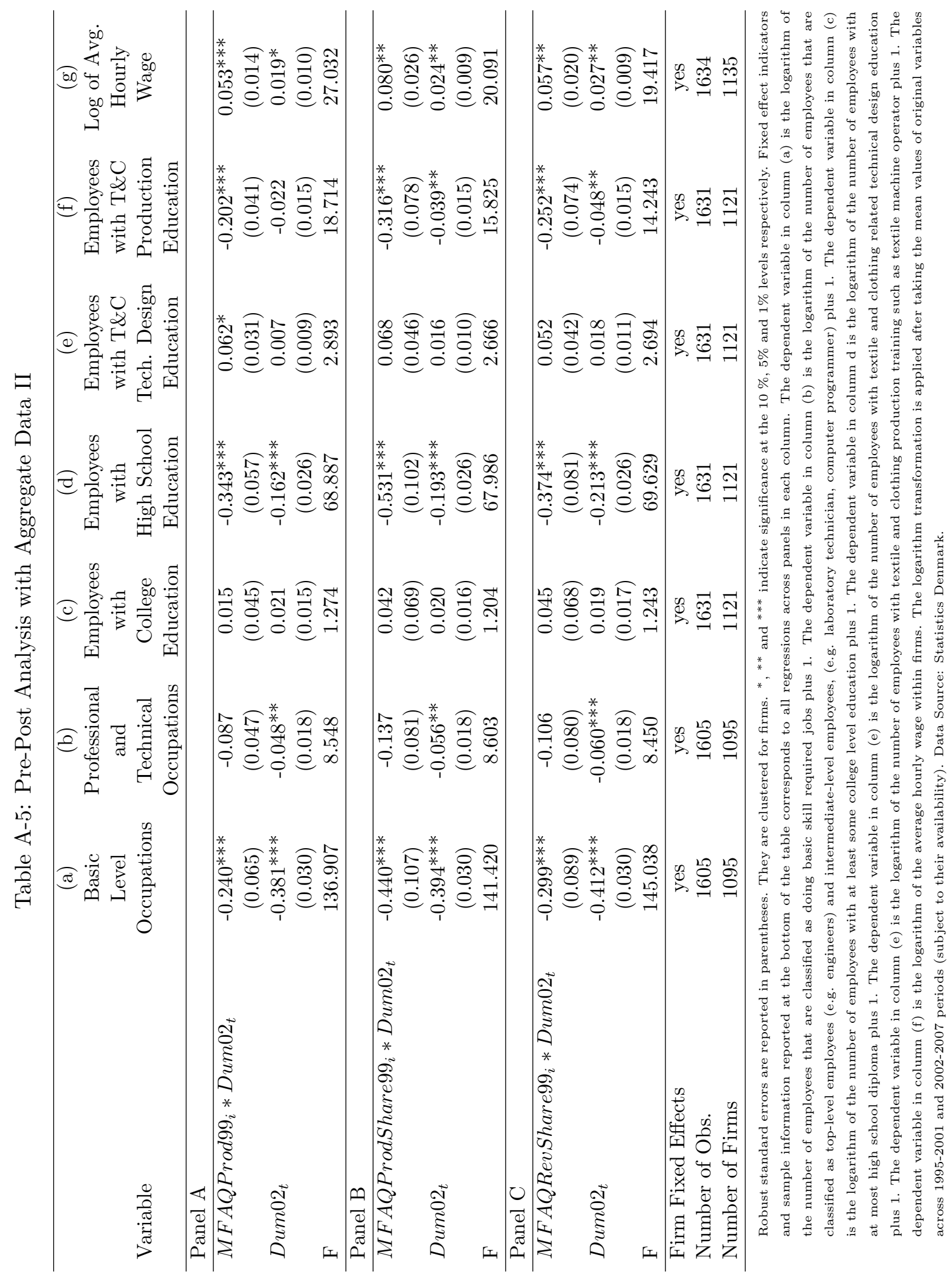


Table A-6: Pre-Post Analysis with Aggregate Data III

\begin{tabular}{|c|c|c|c|c|}
\hline $\begin{array}{l}\text { Sample } \\
\text { Variable }\end{array}$ & $\begin{array}{c}\text { T\&C Manufacturer } \\
\text { (a) } \\
\text { Log Number of } \\
\text { Dropped Products }\end{array}$ & $\begin{array}{l}\text { pre(1996-2001) a } \\
\quad(b) \\
\text { Log Number of } \\
\text { New Products }\end{array}$ & $\begin{array}{l}\text { nd post }(2002-2004) \text { pe } \\
(\mathrm{c}) \\
\text { Log Number of New } \\
\text { Non-MFA Products }\end{array}$ & $\begin{array}{l}\text { ods } \\
\quad(\mathrm{d}) \\
\text { Log Number of New } \\
\text { Non T\&C Products }\end{array}$ \\
\hline \multicolumn{5}{|l|}{ Panel A } \\
\hline MFAQ2Prod $99_{i} *$ Dum02 $2_{t}$ & $\begin{array}{c}0.490^{* * *} \\
(0.083)\end{array}$ & $\begin{array}{c}0.215^{* *} \\
(0.066)\end{array}$ & $\begin{array}{c}0.320^{* * *} \\
(0.067)\end{array}$ & $\begin{array}{c}0.401^{* * *} \\
(0.075)\end{array}$ \\
\hline Dum $02_{t}$ & $\begin{array}{c}0.242^{* * *} \\
(0.037)\end{array}$ & $\begin{array}{c}0.061 \\
(0.034)\end{array}$ & $\begin{array}{c}0.095^{* *} \\
(0.034)\end{array}$ & $\begin{array}{c}0.163^{* * *} \\
(0.038)\end{array}$ \\
\hline $\mathrm{F}$ & 85.038 & 81.757 & 81.725 & 59.155 \\
\hline \multicolumn{5}{|l|}{ Panel B } \\
\hline MFAQ2ProdShare $99_{i} *$ Dum $02_{t}$ & $\begin{array}{c}0.931^{* *} \\
(0.335)\end{array}$ & $\begin{array}{c}0.582^{* *} \\
(0.196)\end{array}$ & $\begin{array}{c}0.823^{* *} \\
(0.255)\end{array}$ & $\begin{array}{c}0.826^{* *} \\
(0.288)\end{array}$ \\
\hline Dum $02_{t}$ & $\begin{array}{c}0.322^{* * *} \\
(0.037)\end{array}$ & $\begin{array}{c}0.090^{* *} \\
(0.032)\end{array}$ & $\begin{array}{c}0.140^{* * * *} \\
(0.031)\end{array}$ & $\begin{array}{c}0.228^{* * *} \\
(0.036)\end{array}$ \\
\hline $\mathrm{F}$ & 89.021 & 83.145 & 81.983 & 56.273 \\
\hline \multicolumn{5}{|l|}{ Panel C } \\
\hline MFAQ2RevShare $99_{i} *$ Dum $02_{t}$ & $\begin{array}{c}0.458 \\
(0.243)\end{array}$ & $\begin{array}{c}0.299 \\
(0.172)\end{array}$ & $\begin{array}{c}0.460^{*} \\
(0.180)\end{array}$ & $\begin{array}{l}0.485^{*} \\
(0.196)\end{array}$ \\
\hline Dum $02_{t}$ & $\begin{array}{c}0.339 * * * \\
(0.037)\end{array}$ & $\begin{array}{c}0.100^{* *} \\
(0.031)\end{array}$ & $\begin{array}{c}0.152^{* * * *} \\
(0.031)\end{array}$ & $\begin{array}{c}0.239 * * * \\
(0.036)\end{array}$ \\
\hline $\mathrm{F}$ & 85.412 & 78.707 & 78.012 & 54.507 \\
\hline Panel D & & & & \\
\hline MFAQProd $99_{i} *$ Dum $02_{t}$ & $\begin{array}{c}0.335^{* * *} \\
(0.069) \\
0.216^{* * *} \\
(0.039) \\
83.564\end{array}$ & $\begin{array}{c}0.182^{* *} \\
(0.058) \\
0.032 \\
(0.039) \\
82.135\end{array}$ & $\begin{array}{c}0.265^{* * *} \\
(0.058) \\
0.055 \\
(0.036) \\
80.667\end{array}$ & $\begin{array}{c}0.337^{* * *} \\
(0.066) \\
0.109^{* *} \\
(0.041) \\
61.306\end{array}$ \\
\hline Firm Fixed Effects & yes & yes & yes & yes \\
\hline Number of Obs. & 1019 & 1020 & 1020 & 1020 \\
\hline Number of Firms & 699 & 716 & 716 & 716 \\
\hline
\end{tabular}

Robust standard errors are reported in parentheses. They are clustered for firms. ${ }^{*},{ }^{* *}$ and ${ }^{* * *}$ indicate significance at the $10 \%, 5 \%$ and $1 \%$ levels respectively. Fixed effect indicators and sample information reported at the bottom of the table corresponds to all regressions across panels in each column. A new product is defined as a product that a firm started to sell/export that current year, which is not observed to be produced by the firm in previous years. A dropped product is defined as a product that a firm stopped selling that current year, and is not observed to be sold by the firm in subsequent years. The logarithm transformation is applied after taking the mean values of original variables across 1996-2001 and 2002-2004 periods. All regressions include size quintiles, where the size is measured as the number of products. Data set Data Source: Statistics Denmark. 
Table A-7: The Impact of Competition on Employment (Year By Year Changes)

\begin{tabular}{|c|c|c|c|}
\hline Variable & $\begin{array}{l}\text { Textile and Apparel } \mathrm{M} \\
\text { (a) } \\
\text { Log No of Employees }\end{array}$ & $\begin{array}{l}\text { anufacturer Firms } \\
\text { (b) } \\
\text { Log No of Base Level } \\
\text { Jobs }\end{array}$ & $\begin{array}{c}(\mathrm{c}) \\
\text { Log No of Employees with } \\
\text { at most } \\
\text { High School Diploma }\end{array}$ \\
\hline MFAQProd $95_{i} * 1996$ & $\begin{array}{l}-0.059 \\
(0.043)\end{array}$ & - & $\begin{array}{l}-0.076 \\
(0.044)\end{array}$ \\
\hline MFAQProd $95_{i} * 1997$ & $\begin{array}{l}-0.017 \\
(0.052)\end{array}$ & $\begin{array}{l}-0.000 \\
(0.041)\end{array}$ & $\begin{array}{l}-0.051 \\
(0.055)\end{array}$ \\
\hline$M F A Q P r o d 95_{i} * 1998$ & $\begin{array}{l}-0.054 \\
(0.056)\end{array}$ & $\begin{array}{l}-0.062 \\
(0.051)\end{array}$ & $\begin{array}{l}-0.071 \\
(0.056)\end{array}$ \\
\hline MFAQProd $95_{i} * 1999$ & $\begin{array}{l}-0.101 \\
(0.071)\end{array}$ & $\begin{array}{l}-0.074 \\
(0.064)\end{array}$ & $\begin{array}{l}-0.120 \\
(0.067)\end{array}$ \\
\hline$M F A Q P r o d 95_{i} * 2000$ & $\begin{array}{l}-0.060 \\
(0.071)\end{array}$ & $\begin{array}{l}-0.024 \\
(0.067)\end{array}$ & $\begin{array}{l}-0.134 \\
(0.069)\end{array}$ \\
\hline MF AQProd $95_{i} * 2001$ & $\begin{array}{l}-0.097 \\
(0.071)\end{array}$ & $\begin{array}{l}-0.075 \\
(0.076)\end{array}$ & $\begin{array}{l}-0.143^{*} \\
(0.072)\end{array}$ \\
\hline MF AQProd $95_{i} * 2002$ & $\begin{array}{c}-0.204^{* *} \\
(0.079)\end{array}$ & $\begin{array}{l}-0.165^{*} \\
(0.081)\end{array}$ & $\begin{array}{c}-0.256^{* *} \\
(0.078)\end{array}$ \\
\hline$M F A Q P r o d 95_{i} * 2003$ & $\begin{array}{l}-0.210^{*} \\
(0.088)\end{array}$ & $\begin{array}{l}-0.079 \\
(0.098)\end{array}$ & $\begin{array}{c}-0.288^{* * *} \\
(0.082)\end{array}$ \\
\hline MF AQProd $95_{i} * 2004$ & $\begin{array}{c}-0.314^{* * *} \\
(0.094)\end{array}$ & $\begin{array}{l}-0.165 \\
(0.102)\end{array}$ & $\begin{array}{c}-0.421^{* * *} \\
(0.088)\end{array}$ \\
\hline MF AQProd $95_{i} * 2005$ & $\begin{array}{c}-0.289^{* *} \\
(0.094)\end{array}$ & $\begin{array}{l}-0.204 \\
(0.108)\end{array}$ & $\begin{array}{c}-0.430^{* * *} \\
(0.089)\end{array}$ \\
\hline$M F A Q P r o d 95_{i} * 2006$ & $\begin{array}{c}-0.292^{* *} \\
(0.105)\end{array}$ & $\begin{array}{l}-0.237^{*} \\
(0.117)\end{array}$ & $\begin{array}{c}-0.418^{* * *} \\
(0.097)\end{array}$ \\
\hline MF AQProd $95_{i} * 2007$ & $\begin{array}{c}-0.328^{* *} \\
(0.108)\end{array}$ & $\begin{array}{l}-0.292^{*} \\
(0.129)\end{array}$ & - \\
\hline Year Fixed Effects & yes & yes & yes \\
\hline Firm Fixed Effects & yes & yes & yes \\
\hline Number of Obs. & 7319 & 6624 & 6893 \\
\hline Number of Firms & 1155 & 1095 & 1095 \\
\hline $\mathrm{F}$ & 6.248 & 19.719 & 10.581 \\
\hline
\end{tabular}

Robust standard errors are reported in parentheses. They are clustered for firms. ${ }^{*},{ }^{* *}$ and ${ }^{* * *}$ indicate significance at the $10 \%, 5 \%$ and $1 \%$ levels respectively. In column a, the dependent variable is the logarithm of employee head-count. In column $\mathrm{b}$, the dependent variable is the logarithm of the number of base-level occupations plus 1 . In column c, the dependent variable is the logarithm of the number of employees with at most high school diploma plus $1 . M F A Q P$ rod $95_{i}$ is an indicator variable that takes 1 if firm i is found to produce MFA quota goods in 1995. Data Source: Statistics Denmark. 
Table A-8: The Impact of Competition on Wages: Worker Level with Firm fixed effects

\begin{tabular}{|c|c|c|c|c|}
\hline Sample & Textile ar & Apparel $\mathrm{M}$ & anufacturer & $(1996-2006)$ \\
\hline Dependent Variable & (a) & $\begin{array}{l}\text { Log of } \mathrm{F} \\
\text { (b) }\end{array}$ & $\begin{array}{l}\text { ourly Wage } \\
\text { (c) }\end{array}$ & (d) \\
\hline MFAQRevShare $99_{i} *$ Dum02 $2_{t}$ & $0.082^{* * *}$ & $\begin{array}{c}0.051^{* * *} \\
(0.015)\end{array}$ & & \\
\hline Gender Dummy (male=1) & & $\begin{array}{c}0.191^{* * *} \\
(0.007)\end{array}$ & $\begin{array}{c}0.191^{* * *} \\
(0.007)\end{array}$ & $\begin{array}{c}0.192^{* * *} \\
(0.007)\end{array}$ \\
\hline Log Worker's Age & & $\begin{array}{c}0.096^{* * *} \\
(0.011)\end{array}$ & $\begin{array}{c}0.096^{* * *} * \\
(0.011)\end{array}$ & $\begin{array}{c}0.096^{* * *} \\
(0.011)\end{array}$ \\
\hline Work Experience & & $\begin{array}{c}0.008^{* * *} \\
(0.001)\end{array}$ & $\begin{array}{c}0.008^{* * *} \\
(0.001)\end{array}$ & $\begin{array}{c}0.008^{* * *} \\
(0.001)\end{array}$ \\
\hline Below High School Dummy & & $\begin{array}{c}-0.059^{* * *} \\
(0.004)\end{array}$ & $\begin{array}{c}-0.059^{* * *} \\
(0.004)\end{array}$ & $\begin{array}{c}-0.056^{* * *} \\
(0.004)\end{array}$ \\
\hline College and Above Dummy & & $\begin{array}{c}0.100^{* * *} \\
(0.008)\end{array}$ & $\begin{array}{c}0.100^{* * *} \\
(0.008)\end{array}$ & $\begin{array}{c}0.097^{* * *} \\
(0.009)\end{array}$ \\
\hline Auxiliary Occupations & & $\begin{array}{c}-0.134^{* * *} \\
(0.012)\end{array}$ & $\begin{array}{l}-0.130^{* * *} \\
(0.012)\end{array}$ & $\begin{array}{l}-0.134^{* * *} \\
(0.012)\end{array}$ \\
\hline Base Level Occupations & & $\begin{array}{l}-0.057^{* * * *} \\
(0.009)\end{array}$ & $\begin{array}{l}-0.054^{* * *} * \\
(0.009)\end{array}$ & $\begin{array}{l}-0.057^{* * *} * \\
(0.009)\end{array}$ \\
\hline Professional Occupations & & $\begin{array}{c}0.139^{* * *} \\
(0.009)\end{array}$ & $\begin{array}{c}0.141^{* * *} * \\
(0.010)\end{array}$ & $\begin{array}{c}0.139 * * * \\
(0.009)\end{array}$ \\
\hline Executives and Employers & & $0.403^{* * *}$ & $0.408^{* * *}$ & $0.402^{* * *}$ \\
\hline MF AQRevShare $99_{i} *$ Dum $02_{t} *$ Unspecified Occup & & & $\begin{array}{l}0.088^{*} \\
(0.039)\end{array}$ & \\
\hline MF AQRevShare $99_{i} *$ Dum02 $2_{t} *$ Auxiliary Occup & & & $\begin{array}{c}0.042 \\
(0.024)\end{array}$ & \\
\hline MFAQRevShare $99_{i} *$ Dum $02_{t} *$ Base level Occup & & & $\begin{array}{c}0.039^{* *} \\
(0.014)\end{array}$ & \\
\hline 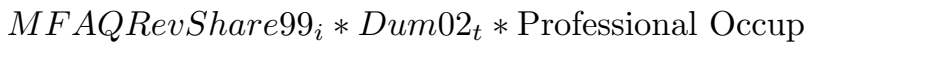 & & & $\begin{array}{l}0.065^{* *} \\
(0.021)\end{array}$ & \\
\hline MF AQRevShare $99_{i} *$ Dum02 $2_{t} *$ Executives and Employers & & & $\begin{array}{c}0.014 \\
(0.051)\end{array}$ & \\
\hline MF AQRevShare $99_{i} *$ Dum02 $2_{t} *$ Below High School & & & & $\begin{array}{c}0.006 \\
(0.015)\end{array}$ \\
\hline MF AQRevShare $99_{i} *$ Dum $02_{t} *$ High School and Vocational & & & & $\begin{array}{c}0.067^{* * *} \\
(0.017)\end{array}$ \\
\hline MF AQRevShare $99_{i} *$ Dum $02_{t} *$ College and Above & & & & $\begin{array}{c}0.107^{* * *} \\
(0.026)\end{array}$ \\
\hline Year Fixed Effects & $\begin{array}{r}\text { yes } \\
\text { ves }\end{array}$ & $\begin{array}{l}\text { yes } \\
\text { ves }\end{array}$ & yes & yes \\
\hline $\begin{array}{l}\text { Number of Obs. } \\
\text { Numbed }\end{array}$ & 102561 & $\begin{array}{c}\text { yes } \\
102561\end{array}$ & $\begin{array}{c}\text { yes } \\
102561\end{array}$ & $\begin{array}{c}\text { yes } \\
102561\end{array}$ \\
\hline Number of Firms & 1034 & 1034 & 1034 & 1034 \\
\hline & 33.045 & 174.078 & 158.987 & 156.870 \\
\hline
\end{tabular}


Table A-9: The Impact of Competition on Wages: Worker Level with Worker Fixed Effects

\begin{tabular}{|c|c|c|c|}
\hline Sample & Textile and $\mathrm{A}$ & parel Manufact & ers (1996-2006) \\
\hline Dependent Variable & $\begin{array}{c}\text { Log of } \\
\text { Hourly Wage } \\
\text { (a) }\end{array}$ & $\begin{array}{c}\text { Log of } \\
\text { Hourly Wage } \\
\text { (b) }\end{array}$ & $\begin{array}{c}\text { Log of } \\
\text { Hourly Wage } \\
\text { (c) }\end{array}$ \\
\hline MFAQRevShare $99_{i} *{\text { Dum } 02_{t}}_{2}$ & $\begin{array}{l}0.045^{* *} \\
(0.015)\end{array}$ & & \\
\hline MFAQRevShare $99_{i}$ & $\begin{array}{r}-0.027^{*} \\
(0.011)\end{array}$ & $\begin{array}{c}-0.029^{* *} \\
(0.011)\end{array}$ & $\begin{array}{c}-0.027^{* *} \\
(0.011)\end{array}$ \\
\hline MF AQRevShare $99_{i} *$ Dum $02_{t} *$ Unspecified Occup & & $\begin{array}{c}0.037^{*} \\
(0.019)\end{array}$ & \\
\hline MFAQRevShare $99_{i} *$ Dum $02_{t} *$ Auxiliary Occup & & $\begin{array}{l}0.035^{*} \\
(0.015)\end{array}$ & \\
\hline MF AQRevShare $99_{i} *$ Dum02 $2_{t} *$ Base Level Occup & & $\begin{array}{l}0.035^{*} \\
(0.014)\end{array}$ & \\
\hline 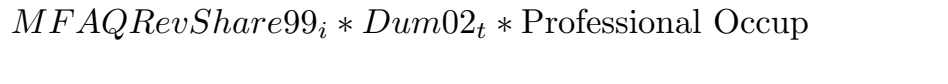 & & $\begin{array}{c}0.116^{* * *} \\
(0.017)\end{array}$ & \\
\hline MFAQRevShare $99_{i} *$ Dum $02_{t} *$ Executives and Employers & & $\begin{array}{l}-0.022 \\
(0.038)\end{array}$ & \\
\hline MF AQRevShare $99_{i} *$ Dum $02_{t} *$ Below High School & & & $\begin{array}{c}0.002 \\
(0.014)\end{array}$ \\
\hline MF AQRevShare $99_{i} *$ Dum $_{2} 2_{t} *$ High School and Vocational & & & $\begin{array}{c}0.057^{* * *} \\
(0.016)\end{array}$ \\
\hline MF AQRevShare $99_{i} *$ Dum $02_{t} *$ College and Above & & & $\begin{array}{c}0.128^{* * *} \\
(0.023)\end{array}$ \\
\hline Year Fixed Effects & yes & yes & yes \\
\hline Worker Fixed Effects & yes & yes & yes \\
\hline Number of Obs. & 102561 & 102561 & 102561 \\
\hline Number of Firms & 1034 & 1034 & 1034 \\
\hline $\mathrm{F}$ & 25.859 & 22.694 & 21.941 \\
\hline
\end{tabular}

Robust standard errors are reported in parentheses. They are clustered for firms. *, ** and $* * *$ indicate significance at the $10 \%, 5 \%$ and $1 \%$ levels respectively. The analysis only covers full-time employees. The source of the data is persondata (IDA), Statistics Denmark. 


\section{B The Impact on T\&C Export}

As in other small open advanced economies, exporting is a very important and relatively common activity for Danish producers. On average every year more than half of all of the Danish Textile and Clothing firms export (52\%) 1] To quantify any significant change in the prices and volumes of Danish textile and clothing exporters observed as a result of the MFA quota removal for Chinese goods, the transaction-level export data-set between 1995 and 2007 is aggregated into firm (i), CN 8-digit product ( $\mathrm{j}$ ), and year (t) level, and equation B-1 is estimated with the dependent variables being the unit price and value of firm i's export $\mathrm{j}$ at period t. In these regressions, instead of deflating unit prices, changes in the price levels specific to textile or clothing industries are controlled for using industry by year fixed effects. Product by firm fixed effects are also included to control for brand/firm specific product prices and qualities.

$$
\begin{array}{r}
\ln X_{i j t}=\alpha_{0}+\alpha_{1} \text { Dum02 }_{t} * M F A Q 2 \text { Exported } 99_{i}+\alpha_{2}{\text { Dum } 05_{t} * M F A Q 5 \text { Exported } 99_{i}+} \\
\delta_{i} * \pi_{j}+\tau_{t} * \nu_{n}+\epsilon_{i j t}
\end{array}
$$

In equation B-1 MF AQ2Exported99 and MFAQ5Exported 99 consist of firms that exported one or more of the MFAQ2 and MFAQ5 products respectively in 1999. The results, which are presented in Table B-1, show that both the 2002 and the 2005 quota removals have significant and negative impact on Danish firms' export. The first two columns indicate that the 2002 quota removal for China had a significant negative effect on export prices of Danish firms while the 2005 quota removal for China had a significant negative effect on export volumes of Danish firms. Columns c and d present the estimation result of equation B-1 when firms that export MFAQ2 and MFAQ5 products in 1999 are combined. Results show that both prices and volumes of exports decreased disproportionately after 2001 among firms that export any MFAQ goods.

\footnotetext{
${ }^{1}$ Many establishment level studies are based on data-sets that contain establishments with 10 or more employees. For the purpose of comparison, among firms that have 10 or more employees the ratio of firms that export (directly) is $82 \%$.
} 
Table B-1: Export Prices and Values

\begin{tabular}{lcccc}
\hline Sample & \multicolumn{4}{c}{ Trade Data: Textile \& Clothing Export 1995-2007 } \\
Variables & Log Price & Log Value & Log Price & Log Value \\
\hline Dum02 $2_{t} *$ MFAQ2Exported $99_{j}$ & $-0.056^{* *}$ & -0.097 & & \\
& $(0.021)$ & $(0.079)$ & \\
Dum05 $5_{t} *$ MFAQ5Export $99_{j}$ & -0.005 & $-0.219^{* *}$ & & \\
& $(0.026)$ & $(0.080)$ & & \\
Dum02 $2_{t} *$ MFAQExported99 $9_{j}$ & & & $-0.063^{* *}$ & $-0.228^{* *}$ \\
& & & $(0.024)$ & $(0.077)$ \\
Industry By Year Fixed Effect & yes & yes & yes & yes \\
Product (CN8) by Firm Fixed Effect & yes & yes & yes & yes \\
Number of Obs. & 279076 & 279189 & 279076 & 279189 \\
F & 5.526 & 5.916 & 5.567 & 5.523 \\
\hline \multicolumn{2}{l}{ Robust standard errors are reported in parentheses. They are clustered for each firm. A constant is included but not re- } \\
$\quad$ ported. The sample covers all reported export transactions in textile and clothing between 1995 and 2007. The transaction- \\
level data set is aggregated into firm-product-year level. Data Source: Statistics Denmark.
\end{tabular}

\section{Constructing Matched Data Sets for the Textile and Cloth- ing Industry}

The data sets used in this study are compiled from different sources mainly within Statistics Denmark. The main data sets are an international trade data-set (Udtræk Udenrigshandel), a domestic sales/production data-set (Udtræk Varestatistik), a firm accounting data-set (Udtræk Regnskabsdata) and a person-level labor market data-set (Udtræk Persondata / IDA). Detailed information on content, coverage and variable definitions of these data-sets can be found at http://www.dst.dk/da/Statistik/dokumentation/times.aspx. Quota information is reported in the SIGL (Système Intégré de Gestion de Licenses) database and is available online at http://trade.ec.europa.eu/sigl/index.html. A brief summary of content and coverage of the confidential data-sets is provided below.

The International trade data-set (Udtræk Udenrigshandel): The international trade data set is compiled from the Danish Customs records. Each shipment record includes the date of the shipment, the value of the shipment, the product code (The Combined Nomenclature (CN) 8-digit), the name of the product, weight of the shipment, unit of weight and, when relevant, quantity information as well as a unique firm identifier. Statistics Denmark aggregated these shipment records into annual shipments for each triplet of product (CN 8-digit), country and 
firm. As provided by Statistics Denmark, the international transaction data-set does not have a truncation at the firm-level as it covers the universe of Danish firms' transactions between 1993 and 2007. However, only product shipments of 10,000 kr (approx. 1700 USD) or more are included in the data set. Unit prices are calculated using uniform measures of weight/quantity for each product.

Domestic trade data (Udtræk Varestatistik): The industry's sales of products are recorded in the 10-digit product classification. The first 8 digits of the classification of goods is always identical to the combined nomenclature. This data-set is available for the period 1995-2005. Only firms with employment of 10 people or more two years prior to current (statistics) date are included in this survey.

Firm Accounting data (Udtræk Regnskabsdata): Business statistics data are compiled from survey results of firms that take part in an annual financial survey as well as from the annual tax reports, vat reports, and annual reports from incorporated companies. The general business statistics include only firms that employ at least a 0.5 FTE (full-time equivalent employment) employment and/or have had estimated earnings of a certain size $2^{2}$. However, some of the data for small firms may be subject to imputation. This data-set is available starting from 1995. Only manufacturing, construction and retail sectors are included until 1998. In 1998, the wholesale trade sector is included and starting from 1999 it covers almost all sectors including mining, and all business service sectors $?^{3}$

Integrated Database for Labour Market Research (IDA): A longitudinal yearly data-set of persons (age 15-70) are merged with establishments. It contains establishment and industry codes, education-level, wages, type of jobs, work experience, age, and other person classifications. For a complete description see the Danmarks Statistik document at http://www.dst.dk/da/Statistik/ dokumentation/Times/ida-databasen.aspx.

All of the data-sets are accessed through the LMDG (Labor Market Development and Growth)

\footnotetext{
${ }^{2}$ In the wholesale trade sectors, the limit of earnings is typically at 500,000 Danish Kroner, while in the manufacturing industry, it ranges between 150,000 and 200,000 Danish Kroner.

${ }^{3}$ Starting from 1999, the data-set includes hospitality, transportation, telecommunication, real estate, rental services, information technology services, research and development services, and other consultancy and business services. It does not include agriculture, financial sector, public, education and medical service sectors.
} 
project sponsored servers, and the routine cleaning procedures have been executed both by Statistics Denmark and also by the LMDG. For details of the cleaning procedures conducted by the LMDG project, see Bunzel (2008).

\section{C-I Firm-Level Values}

Raw materials, intermediate goods, capital goods, electric, gas, water, and output deflators provided by Statistics Denmark are used to deflate the nominal variables. Wages are deflated using cpi. Sales and output values are deflated separately for textile and apparel producers using the output deflators. Value-added information is derived by the author using the following formula: [turnover + work performed for own purposes and capitalized + (end of year inventory - beginning of year inventory) - [purchase of raw materials + energy + subcontracting expenses]. Values, except hourly wages, are expressed in thousands year 2000 constant Danish Kroner. Hourly wages are expressed in constant year 2000 Danish kroner. Physical capital assets include plant, machinery, technical installations, land, buildings, and other equipment such as computers, and office furniture. Table C-1 and C-2 present summary statistics for firm-level variables from the Regnskabsdata and IDA data-sets.

Table C-1: Summary Statistics I

\begin{tabular}{lccccc}
\hline Source & \multicolumn{2}{c}{ Regnskabsdata } & & & \\
Variables & $\mathrm{N}$ & Median & Mean & Standard Deviation & Sample \\
\hline Turnover & 7275 & 5092.5 & 21560.3 & 54842.8 & $1995-2007$ \\
Value Added & 7275 & 2675.0 & 9766.5 & 24030.3 & $1995-2007$ \\
Profit & 7275 & 239.9 & 1252.7 & 7047.5 & $1995-2007$ \\
Total Assets & 7275 & 3564.0 & 17970.2 & 68447.1 & $1995-2007$ \\
Capital & 7275 & 928.0 & 5271.7 & 21617.9 & $1995-2007$ \\
Investment & 7275 & 131.8 & 1052.2 & 6645.0 & $1995-2007$ \\
Firm Age & 6738 & 13.0 & 15.3 & 12.2 & $1995-2007$ \\
Full-time Equivalent Labor & 7275 & 5.9 & 18.0 & 39.4 & $1995-2007$ \\
Average Full Wage (Per Person) & 7213 & 261.8 & 275.4 & 108.5 & $1995-2007$ \\
\hline
\end{tabular}

Values are expressed in constant year 2000 prices in thousand Danish kroner. Source: Statistics Denmark. 
Table C-2: Summary Statistics II

\begin{tabular}{lccccc}
\hline Source & IDA & & & & \\
Variables & $\mathrm{N}$ & Median & Mean & Standard Deviation & Sample \\
\hline Head-Count Labor & 7319 & 7.0 & 20.0 & 41.3 & $1995-2007$ \\
Vocational Educ. and Above & 6893 & 3.0 & 9.0 & 19.5 & $1995-2006$ \\
High School and Below & 6893 & 4.0 & 10.5 & 2.1 & $1995-2006$ \\
Executives and Employers & 7319 & 1.0 & 1.2 & 1.9 & $1996-2007$ \\
Top and Mid Level Occupations & 7319 & 0.0 & 2.7 & 7.3 & $1996-2007$ \\
Base Level Occupations & 6624 & 3.0 & 10.9 & 27.3 & $1996-2007$ \\
Auxiliary Occupations & 6624 & 0.0 & 1.5 & 5.2 & $1996-2007$ \\
Unspecified Occupations & 6624 & 2.0 & 3.0 & 6.7 & $1996-2007$ \\
Average Hourly Wage & 7074 & 142.3 & 144.9 & 36.1 & $1995-2007$ \\
\hline
\end{tabular}

Values are expressed in constant year 2000 prices in Danish kroner. Source: Statistics Denmark.

\section{C-II Employee Characteristics (IDA)}

Every person is attached a code regarding his/her status within the firm. In order to comply with the major groupings of the the International Standard Classification of Occupations Codes (ISCO-88), The Danish statistics created a Danish version of ISCO-88, called DISCO-88, in 1996 to replace the previous categorization. So there is a discontinuity between the codes between pre and post 1996 data and so the analysis of occupation characteristics does not include data for the year 1995. Inactive people in the payroll such as retirees, employees on leave as well as owners' spouses are dropped before calculating the employment characteristics for each firm.

The classifications of occupations are derived from the variable 'pstill2'. Occupation categories are 'employer', 'executive', 'top-level employee', 'intermediate-level employee', 'auxiliary employee' and 'unspecified'. The professional and technical occupations in the analysis correspond to the 'pstill2' values 32 and 34, which are top-level professional employees and intermediate level professional and technical employees, respectively. The classification of base-level occupations corresponds to the pstill2 value 35, which includes work that requires basic level skills, such as office work or operating different types of stationary machinery. The classification of auxiliary employee (employees with no skill requirement) refers to the pstill2 value 36, which includes work such as cleaning services, delivery services, guard work, and transport work. The last grouping, pstill2 value 37, contains occupations that are unclassified due to various reasons. 
The educational backgrounds of employees are obtained from the 8-digit education code, 'hffsp', that shows the person's maximum completed education level combined with professional training. Since 8-digit education codes are not reported in 2007 , the relevant education variables are not constructed for that year. The first two digits of the code indicate the main education groups. The group of people with at most high school diploma refers to a hffsp value with the first two digits at 25 or below. The group of people with at least some college schooling refers to a hffsp value with the first two digits equal to or larger than 40. Employees with professional training (college level) in technical design in textile and clothing industry corresponds to hffsp value 405985, it includes industrial designer, model engineering, product developer, textile and garment engineering training. Employees with production training in textile and clothing industry corresponds to hffsp values 355880 and 355890, it includes clothing operator, fashion craft, hand stitchers, cutter, tailor, knitting operator, textile operator, textile worker etc..Skill or vocational training in Denmark is provided by the technical high schools (after 9 years of mandatory schooling) and involves several years of formalized training including both schooling and apprenticeship. For example being a tailor requires between 3 years and 3 years and 4 months skill education or being an industry operator requires between 2 years and 2 years and 8 months education depending on additional qualifications.

In the labor (IDA) data-set, for each employed person there is a unique firm identifier provided for the employer. Using this firm identifier, extracted information from IDA is merged with the Firm Accounting Data Set for each year. Only a couple of observations in the firm accounting data are left unmatched from this matching.

\section{C-III Product Characteristics}

The product classifications are based on The Combined Nomenclature $(\mathrm{CN})$. It is comprised of the Harmonized System (HS) nomenclature with further European Community subdivisions. The first six digits of the classification matches with the Harmonized System. A detailed description of the $\mathrm{CN}$ codes can be found at http://udr.dst.dk/nomenklatur/index.aspx. Export data between 1993 and 2007 and domestic sales/production data between 1995 and 2005 are merged to construct product portfolios of firms. The first eight digits of the product cate- 
gories in the domestic sales data are the same as the combined nomenclature $(\mathrm{CN})$ reported in the international trade data. Quota categories for China, which are reported in the SIGL (Système Intégré de Gestion de Licenses) database, are assigned CN codes based on CN 1999. This is done by going over the description of each quota category as well as each CN 8-digit product and confirming it using Annex I of the "Council Regulation (EEC) No 3030/93 of 12 October 1993 on common rules for imports of certain textile products from third countries" which reports the CN 2009 correspondence of the quota categories. The annex is available at the SIGL. The resulting CN correspondence of the quotas for China are linked back and forth through years using correspondence tables linking CN 1995 through CN 2007 as provided by the European Commission-Eurostat. Most of the quotas for China were utilized above $90 \%$ but there were some additional quotas designed only for China which involved silk and rami fabrics. Since some of these additional quotas were not utilized, the empirical analysis focuses on quotas for China that were utilized at at least $10 \%$ prior to their removals. The matchings of the $\mathrm{CN}$ codes to the quota categories are available from the author.

Product classifications as new products or dropped products are made according to the 8digit classification. Products are defined in $\mathrm{CN}$ 8-digit in the analysis if not otherwise stated. Analyses with 6-digit product classification are also available upon request. Table C-3 presents summary statistics. The median number of 8 -digit products produced among the Textile and Apparel firms is 6 . About $42 \%$ of the firms are found to produce between 1 and 5 products as shown in Table C-4. Table C-5 also shows the transition probabilities for firms between the number of products they produce. For firms producing 1 to 5 products in one period, the probability of producing 1 to 5 products in the next period is about 84 percent.

Table C-3: Summary Statistics III

\begin{tabular}{lccccc}
\hline Source & \multicolumn{6}{c}{ Custom and Domestic Sales Data Sets } \\
Variables & N & Median & Mean & Standard Deviation & Sample \\
\hline Number of 8-digit Products & 4218 & 6 & 16.955 & 30.185 & $1995-2005$ \\
Number of 6-digit Products & 4218 & 6 & 15.240 & 26.082 & $1995-2005$ \\
Number of New Products & 3467 & 2 & 6.491 & 12.972 & $1996-2005$ \\
Number of New Non-MFAQ Products & 3467 & 2 & 5.041 & 10.620 & $1996-2005$ \\
Number of New Non-T\&C Products & 3467 & 0 & 2.560 & 7.967 & $1996-2005$ \\
Number of Dropped Products & 3609 & 2 & 5.365 & 11.593 & $1995-2004$ \\
\hline
\end{tabular}

Source: Statistics Denmark. 
Table C-4: Distribution of Firms Over the Number of Products

\begin{tabular}{rrrrrrr}
\hline Sample & \multicolumn{6}{c}{ Textile and Apparel Manufacturers 1995-2005 } \\
\# of 8-digit products & $\mathbf{1 - 5}$ & $\mathbf{6 - 1 0}$ & $\mathbf{1 1 - 1 5}$ & $\mathbf{1 6 - 2 0}$ & $\mathbf{2 1 - 2 5}$ & $\mathbf{2 5 +}$ \\
\hline Percentages & 41.68 & 15.88 & 10.13 & 6.78 & 4.85 & 20.67 \\
\hline
\end{tabular}

Source: Statistics Denmark.

Table C-5: Transition Matrix between the Number of Products

\begin{tabular}{rrrrrrrl}
\hline & \multicolumn{6}{c}{ Number of Products at $t+1$} \\
\# of 8-digit products at $t$ & $\mathbf{1 - 5}$ & $\mathbf{6 - 1 0}$ & $\mathbf{1 1 - 1 5}$ & $\mathbf{1 6 - 2 0}$ & $\mathbf{2 1 - 2 5}$ & $\mathbf{2 5 +}$ \\
\hline $\mathbf{1 - 5}$ & 84.33 & 10.61 & 2.31 & 1.08 & 0.22 & 1.44 \\
$\mathbf{6 - 1 0}$ & 24.59 & 46.97 & 17.80 & 6.06 & 1.47 & 3.12 \\
$\mathbf{1 1 - 1 5}$ & 4.78 & 25.48 & 41.40 & 14.01 & 6.37 & 7.96 \\
$\mathbf{1 6 - 2 0}$ & 5.58 & 5.12 & 20.93 & 37.67 & 14.88 & 15.81 \\
$\mathbf{2 1 - 2 5}$ & 3.75 & 3.75 & 8.13 & 18.13 & 30.63 & 35.63 \\
$\mathbf{2 5 +}$ & 1.00 & 1.84 & 1.51 & 2.68 & 7.36 & 85.62 \\
\hline
\end{tabular}

Source: Statistics Denmark.

\section{Supplemental Analysis}

- Table D-1 presents the share of imports in textile and clothing industry in Denmark from countries that experience quota removal during the second phase of the abolishment of MFA quotas.

- Table D-2 presents the average numbers of employees in jobs that require basic skills and professional skills respectively across treated firms (MFAQ producers in 1999) and untreated firms.

- Table D-3 presents the average numbers of employees with no high school diploma and with college education respectively across treated firms (MFAQ producers in 1999) and untreated firms.

- Figure D-1 shows the evolution of the ratio of employees with professional occupations to employees in jobs that require basic skills. 
- Table D-4 presents main results when only the 2005 quota removal is considered as treatment. These results are obtained by re-doing the main analysis presented in the paper with a treatment variable that covers firms affected by the 2005 quota removal for China.

- Table D-5 presents main results when only the 2002 quota removal is considered as treatment. These results are obtained by re-doing the main analysis presented in the paper with a treatment variable that covers firms affected by the 2002 quota removal for China.

- Table D-6 presents main results when the 2002 and 2005 quota removals are considered as treatments separately within the same analysis.

- Table D-7 and Table D-8 present the analysis using a two stage least squares method where Chinese competition is proxied with the firm-specific Chinese import measure.

- Table D-9 presents results where firms' age is additionally controlled for. Since firms' age is not reported for every firm, the number of observations drop.

- Tables D-10 and D-11 present results where entry and exit of firms are controlled for in addition to firms' age. The entry variable is not defined in 1995 and the exit variable is not defined in 2007. Hence the sample period for this analysis is 1996-2006.

- Table D-12 repeats the analysis of product churning presented in Table 7 of the paper without controlling for size quintile dummies.

- Table D-13 presents an analysis of profit.

- Table D-14 presents a probit analysis of profit to understand if firms' switching from positive to negative profit is correlated with the Chinese competition.

- Table D-15 presents a probit analysis of firm exit. 


\section{D-I Phase II Quota Removal}

Table D-1: Phase II Imports

\begin{tabular}{ccccccc}
\hline \hline \multicolumn{7}{c}{ \% of Import from Countries that face quota removal in 1998} \\
Year & EEC & Argentina & Brazil & Hong Kong & Korea & Macao \\
\hline 1995 & 0.0820 & 0.0000 & 0.0010 & 0.0413 & 0.0071 & 0.0077 \\
1996 & 0.0827 & 0.0000 & 0.0007 & 0.0409 & 0.0069 & 0.0089 \\
1997 & 0.0832 & 0.0004 & 0.0007 & 0.0392 & 0.0090 & 0.0100 \\
1998 & 0.0866 & 0.0003 & 0.0003 & 0.0345 & 0.0091 & 0.0075 \\
1999 & 0.0878 & 0.0001 & 0.0003 & 0.0383 & 0.0108 & 0.0078 \\
2000 & 0.0839 & 0.0000 & 0.0003 & 0.0382 & 0.0117 & 0.0077 \\
2001 & 0.0862 & 0.0000 & 0.0003 & 0.0320 & 0.0101 & 0.0073 \\
2002 & 0.0736 & 0.0000 & 0.0003 & 0.0261 & 0.0083 & 0.0063 \\
2003 & 0.0561 & 0.0000 & 0.0004 & 0.0202 & 0.0064 & 0.0061 \\
2004 & 0.0519 & 0.0000 & 0.0003 & 0.0212 & 0.0064 & 0.0058 \\
2005 & 0.0370 & 0.0000 & 0.0003 & 0.0159 & 0.0044 & 0.0037 \\
2006 & 0.0441 & 0.0000 & 0.0004 & 0.0266 & 0.0044 & 0.0044 \\
2007 & 0.0419 & 0.0000 & 0.0002 & 0.0192 & 0.0030 & 0.0035 \\
\hline
\end{tabular}

The EEC column is the sum of import shares of all EEC countries that experienced textile quota removal in 1998. They are Bulgaria, Romania, Poland, Czech Republic, Slovakia, and Hungary. Data Source: Statistics Denmark. 


\section{D-II Labor Changes Among Treated Firms versus Untreated Firms}

Table D-2: Summary Statistics: Occupation Composition Among Treated versus Untreated Firms

\begin{tabular}{lccccc}
\hline Size (in FTE) & Year & \multicolumn{2}{c}{ Base-Level Occupations } & \multicolumn{2}{c}{ Professional Occupations } \\
\cline { 3 - 6 }$>100$ & & Average & Average & Average & Average \\
& & Among Treated & Among Untreated & Among Treated & Among Untreated \\
& $1996-2001$ & 114.275 & 75.102 & 28.691 & 9.245 \\
$30-100$ & $2002-2006$ & 78.537 & 63.712 & 29.292 & 10.039 \\
& & & & & \\
\multirow{3}{*}{$10-30$} & $1996-2001$ & 34.523 & 33.512 & 8.544 & 5.743 \\
& $2002-2006$ & 27.071 & 31.414 & 10.897 & 5.748 \\
& $1996-2001$ & 11.507 & & & \\
& $2002-2006$ & 8.065 & 12.274 & 3.259 & 1.912 \\
& & & 9.273 & 3.174 & 2.174 \\
\hline
\end{tabular}

Source: Statistics Denmark.

Table D-3: Summary Statistics: Skill Composition Among Treated versus Untreated Firms

\begin{tabular}{lccccc}
\hline Size (in FTE) & Year & \multicolumn{2}{c}{ No High School Diploma } & \multicolumn{2}{c}{ College Education } \\
\cline { 3 - 6 }$>100$ & & Average & Average & Average & Average \\
& & Among Treated & Among Untreated & Among Treated & Among Untreated \\
& $1996-2001$ & 80.632 & 47.204 & 20.374 & 11.627 \\
$30-100$ & $2002-2006$ & 55.171 & 42.036 & 24.990 & 14.202 \\
& & & & & \\
\multirow{3}{*}{$10-30$} & $1996-2001$ & 25.697 & 24.510 & 6.966 & 5.666 \\
& $2002-2006$ & 20.583 & 24.162 & 10.680 & 7.189 \\
& $1996-2001$ & 8.901 & & & \\
& $2002-2006$ & 6.685 & 9.412 & 2.331 & 1.775 \\
& & & 7.496 & 3.111 & 1.980 \\
\hline
\end{tabular}

Source: Statistics Denmark. 


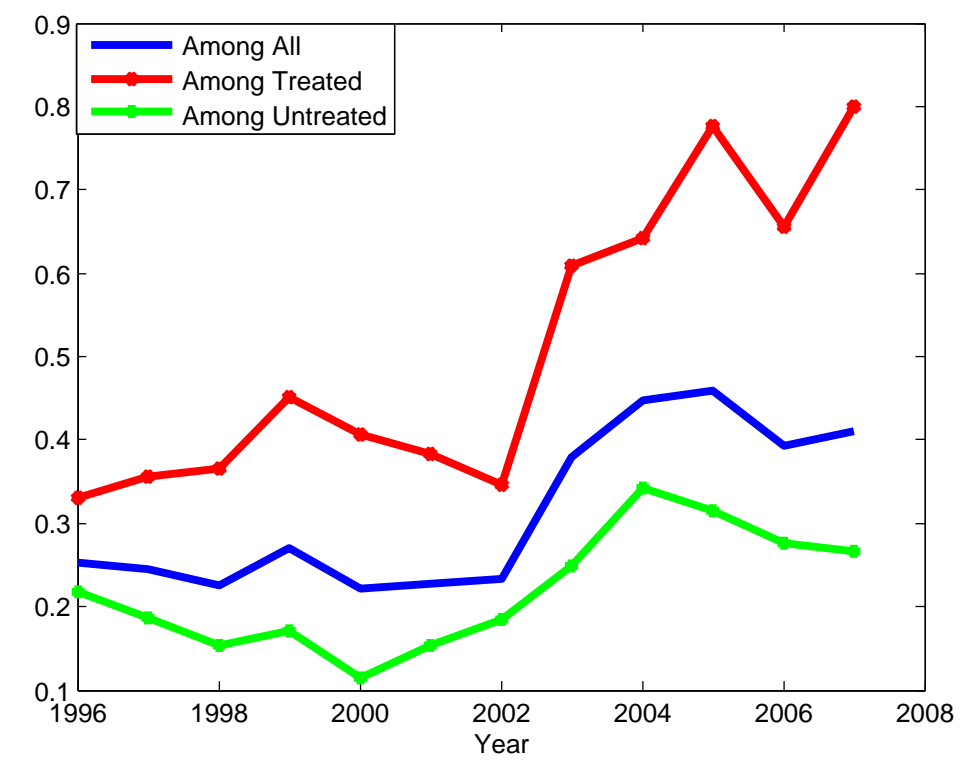

Figure D-1: The Ratio of Professional and Technical (Top and Mid) Occupations to Base Level Occupations (Source: Statistics Denmark.) 


\section{D-III Separate Analyses of the Impacts of the 2002 and 2005 Quota Re- movals}

Table D-4: Separate Analysis for the 2005 Quota Removal Experience

\begin{tabular}{|c|c|c|c|c|}
\hline & (a) & (b) & (c) & (d) \\
\hline $\begin{array}{l}\text { Panel A } \\
\text { Variable }\end{array}$ & Log Turnover & Log Value Added & Log FTE & Log Labor \\
\hline \multirow{2}{*}{ MF AQ5 Prod $99_{i} *$ Dum $_{05_{t}}$} & $-0.156^{*}$ & $-0.185^{*}$ & $-0.191^{* *}$ & $-0.148^{*}$ \\
\hline & $(0.070)$ & $(0.077)$ & $(0.070)$ & $(0.064)$ \\
\hline Year Fixed Effects & yes & yes & yes & yes \\
\hline Firm Fixed Effects & yes & yes & yes & yes \\
\hline Number of Obs. & 7274 & 7252 & 7213 & 7319 \\
\hline $\mathrm{F}$ & 3.185 & 6.642 & 10.101 & 10.459 \\
\hline \multicolumn{5}{|l|}{ Panel B } \\
\hline & $\begin{array}{c}\text { Employees } \\
\text { with at least }\end{array}$ & $\begin{array}{c}\text { Employees } \\
\text { with at most }\end{array}$ & $\begin{array}{l}\text { Employees } \\
\text { with T\&C }\end{array}$ & $\begin{array}{l}\text { Employees } \\
\text { with T\&C }\end{array}$ \\
\hline Variable & College Educ. & High School Educ. & Production Educ. & Technical Design Educ. \\
\hline \multirow[t]{2}{*}{$M F A Q 5 \operatorname{Prod} 99_{i} *$ Dum $05_{t}$} & 0.041 & $-0.244^{* * *}$ & $-0.112^{*}$ & 0.082 \\
\hline & $(0.048)$ & $(0.055)$ & $(0.044)$ & $(0.043)$ \\
\hline Year Fixed Effects & yes & yes & yes & yes \\
\hline Firm Fixed Effects & yes & yes & yes & yes \\
\hline Number of Obs. & 6893 & 6893 & 6893 & 6893 \\
\hline $\mathrm{F}$ & 2.325 & 17.119 & 3.480 & 3.312 \\
\hline \multicolumn{5}{|l|}{ Panel C } \\
\hline & Auxiliary and Base & Base & Professional and & Average \\
\hline & Level & Level & Technical & Hourly \\
\hline Variable & Occupations & Occupations & Occupations & Wage \\
\hline \multirow[t]{2}{*}{$M F A Q 5 \operatorname{Prod}_{99_{i}} *$ Dum $05_{t}$} & $-0.198^{* *}$ & $-0.209^{* *}$ & 0.024 & $0.036^{*}$ \\
\hline & $(0.073)$ & $(0.076)$ & $(0.051)$ & $(0.015)$ \\
\hline Year Fixed Effects & yes & yes & yes & yes \\
\hline Firm Fixed Effects & yes & yes & yes & yes \\
\hline Number of Obs. & 6624 & 6624 & 6624 & 7074 \\
\hline $\mathrm{F}$ & 35.628 & 35.751 & 4.820 & 10.177 \\
\hline \multicolumn{5}{|l|}{ Panel D } \\
\hline & Log Capital & Log Intangible & Log Investment & Log Capital \\
\hline Variable & & Assets & & Per Labor \\
\hline \multirow[t]{2}{*}{ MFAQ5Prod $99_{i} * \operatorname{Dum}_{0} 5_{t}$} & 0.157 & -0.212 & $-0.352^{*}$ & $0.332^{* *}$ \\
\hline & $(0.119)$ & $(0.169)$ & $(0.147)$ & $(0.124)$ \\
\hline Year Fixed Effects & yes & yes & yes & yes \\
\hline Firm Fixed Effects & yes & yes & yes & yes \\
\hline Number of Obs. & 7115 & 5845 & 6598 & 7054 \\
\hline $\mathrm{F}$ & 15.010 & 83.877 & 32.296 & 16.032 \\
\hline
\end{tabular}


Table D-5: Separate Analysis for the 2002 Quota Removal Experience

\begin{tabular}{|c|c|c|c|c|}
\hline & (a) & (b) & (c) & (d) \\
\hline \multicolumn{5}{|l|}{ Panel A } \\
\hline Variable & Log Turnover & Log Value Added & Log FTE & Log Labor \\
\hline \multirow[t]{2}{*}{ MFAQ2Prod $99_{i} *$ Dum $02_{t}$} & -0.058 & -0.072 & $-0.191^{* *}$ & $-0.166^{*}$ \\
\hline & $(0.075)$ & $(0.074)$ & $(0.074)$ & $(0.071)$ \\
\hline Year Fixed Effects & yes & yes & yes & yes \\
\hline Firm Fixed Effects & yes & yes & yes & yes \\
\hline Number of Obs. & 7274 & 7252 & 7213 & 7319 \\
\hline $\mathrm{F}$ & 2.967 & 6.052 & 9.582 & 10.319 \\
\hline \multicolumn{5}{|l|}{ Panel B } \\
\hline & Employees & Employees & Employees & Employees \\
\hline & with at least & with at most & with T\&C & with T\&C \\
\hline Variable & College Educ. & High School Educ. & Production Educ. & Technical Design Educ. \\
\hline \multirow[t]{2}{*}{ MFAQ2Prod $99_{i} *$ Dum02 $t$} & $0.137^{*}$ & $-0.248^{* * *}$ & $-0.226^{* * *}$ & $0.147^{* *}$ \\
\hline & $(0.059)$ & $(0.064)$ & $(0.060)$ & $(0.052)$ \\
\hline Year Fixed Effects & yes & yes & yes & yes \\
\hline Firm Fixed Effects & yes & yes & yes & yes \\
\hline Number of Obs. & 6893 & 6893 & 6893 & 6893 \\
\hline $\mathrm{F}$ & 2.493 & 16.710 & 3.660 & 3.249 \\
\hline \multicolumn{5}{|l|}{ Panel C } \\
\hline & Auxiliary and Base & Base & Professional and & Average \\
\hline & Level & Level & Technical & Hourly \\
\hline Variable & Occupations & Occupations & Occupations & Wage \\
\hline \multirow[t]{2}{*}{ MF AQ2Prod $99_{i} *$ Dum $02_{t}$} & -0.113 & -0.099 & -0.040 & $0.047^{* * *}$ \\
\hline & $(0.086)$ & $(0.091)$ & $(0.066)$ & $(0.013)$ \\
\hline Year Fixed Effects & yes & yes & yes & yes \\
\hline Firm Fixed Effects & yes & yes & yes & yes \\
\hline Number of Obs. & 6624 & 6624 & 6624 & 7074 \\
\hline $\mathrm{F}$ & 35.494 & 35.622 & 4.679 & 11.452 \\
\hline \multicolumn{5}{|l|}{ Panel D } \\
\hline & Log Capital & Log Intangible & Log Investment & Log Capital \\
\hline Variable & & Assets & & Per Labor \\
\hline \multirow[t]{2}{*}{$M F A Q 2 \operatorname{Prod} 99_{i} *$ Dum $02_{t}$} & 0.079 & $-0.621^{* * *}$ & -0.182 & $0.255^{*}$ \\
\hline & $(0.116)$ & $(0.168)$ & $(0.122)$ & $(0.106)$ \\
\hline Year Fixed Effects & yes & yes & yes & yes \\
\hline Firm Fixed Effects & yes & yes & yes & yes \\
\hline $\mathrm{F}$ & 14.850 & 81.756 & 31.685 & 15.893 \\
\hline Number of Obs. & 7115 & 5845 & 6598 & 7054 \\
\hline
\end{tabular}


Table D-6: Separate Analysis for the 2002 and 2005 Quota Removal Experience

\begin{tabular}{|c|c|c|c|c|}
\hline & (a) & (b) & (c) & (d) \\
\hline \multicolumn{5}{|l|}{ Panel A } \\
\hline Variable & Log Turnover & Log Value Added & Log FTE & Log Labor \\
\hline \multirow[t]{2}{*}{ MFAQ 2 Prod $99_{i} *$ Dum $02_{t}$} & -0.018 & -0.025 & $-0.152^{*}$ & $-0.137^{*}$ \\
\hline & $(0.071)$ & $(0.069)$ & $(0.069)$ & $(0.069)$ \\
\hline \multirow[t]{2}{*}{$M F A Q 5 \operatorname{Prod} 99_{i} *$ Dum $05_{t}$} & $-0.151^{*}$ & $-0.178^{*}$ & $-0.150^{*}$ & -0.111 \\
\hline & $(0.064)$ & $(0.071)$ & $(0.064)$ & $(0.061)$ \\
\hline Year Fixed Effects & yes & yes & yes & yes \\
\hline Firm Fixed Effects & yes & yes & yes & yes \\
\hline Number of Obs. & 7274 & 7252 & 7213 & 7319 \\
\hline $\mathrm{F}$ & 2.970 & 6.458 & 9.350 & 9.771 \\
\hline \multicolumn{5}{|l|}{ Panel B } \\
\hline & $\begin{array}{c}\text { Employees } \\
\text { with at least }\end{array}$ & $\begin{array}{c}\text { Employees } \\
\text { with at most }\end{array}$ & $\begin{array}{l}\text { Employees } \\
\text { with T\&C }\end{array}$ & $\begin{array}{l}\text { Employees } \\
\text { with T\&C }\end{array}$ \\
\hline Variable & College Educ. & High School Educ. & Production Educ. & Technical Design Educ. \\
\hline \multirow[t]{2}{*}{$M F A Q 2 \operatorname{Prod} 99_{i} *$ Dum $02_{t}$} & $0.136^{*}$ & $-0.209^{* *}$ & $-0.215^{* * *}$ & $0.137^{* *}$ \\
\hline & $(0.058)$ & $(0.063)$ & $(0.059)$ & $(0.049)$ \\
\hline \multirow[t]{2}{*}{$M F A Q 5 \operatorname{Prod} 99_{i} *$ Dum $05_{t}$} & 0.004 & $-0.188^{* * *}$ & -0.053 & 0.044 \\
\hline & $(0.044)$ & $(0.053)$ & $(0.040)$ & $(0.037)$ \\
\hline Year Fixed Effects & yes & yes & yes & yes \\
\hline Firm Fixed Effects & yes & yes & yes & yes \\
\hline Number of Obs. & 6893 & 6893 & 6893 & 6893 \\
\hline $\mathrm{F}$ & 2.403 & 16.102 & 3.401 & 3.191 \\
\hline \multicolumn{5}{|l|}{ Panel C } \\
\hline & Auxiliary and Base & Base & Professional and & Average \\
\hline & Level & Level & Technical & Hourly \\
\hline Variable & Occupations & Occupations & Occupations & Wage \\
\hline \multirow{2}{*}{ MF AQ2Prod $99_{i} * \operatorname{Dum}_{02} 2_{t}$} & -0.067 & -0.049 & -0.021 & $0.040^{* *}$ \\
\hline & $(0.083)$ & $(0.087)$ & $(0.159)$ & $(0.013)$ \\
\hline \multirow[t]{2}{*}{ MF AQ5Prod $99_{i} *$ Dum $05_{t}$} & $-0.180^{* *}$ & $-0.196^{* *}$ & -0.002 & 0.025 \\
\hline & $(0.068)$ & $(0.070)$ & $(0.084)$ & $(0.015)$ \\
\hline Year Fixed Effects & yes & yes & yes & yes \\
\hline Firm Fixed Effects & yes & yes & yes & yes \\
\hline Number of Obs. & 6624 & 6624 & 6624 & 7074 \\
\hline $\mathrm{F}$ & 32.878 & 33.020 & 4.351 & 11.210 \\
\hline \multicolumn{5}{|l|}{ Panel D } \\
\hline & Log Capital & Log Intangible & Log Investment & Log Capital \\
\hline Variable & & Assets & & Per Labor \\
\hline \multirow[t]{2}{*}{ MFAQ2Prod $99_{i} *$ Dum02 $2_{t}$} & 0.041 & $-0.609^{* * *}$ & -0.107 & 0.182 \\
\hline & $(0.117)$ & $(0.172)$ & $(0.123)$ & $(0.106)$ \\
\hline \multirow{2}{*}{$M F A Q 5 \operatorname{Prod} 99_{i} * D u m 05_{t}$} & 0.146 & -0.047 & $-0.320^{*}$ & $0.281^{*}$ \\
\hline & $(0.120)$ & $(0.169)$ & $(0.149)$ & $(0.126)$ \\
\hline Year Fixed Effects & yes & yes & yes & yes \\
\hline Firm Fixed Effects & yes & yes & yes & yes \\
\hline Number of Obs. & 7115 & 5845 & 6598 & 7054 \\
\hline $\mathrm{F}$ & 13.928 & 76.141 & 30.071 & 14.994 \\
\hline
\end{tabular}




\section{D-IV Two Stage Regressions}

Table D-7: Two Stage Regressions I

\begin{tabular}{|c|c|c|c|c|}
\hline \multirow[t]{2}{*}{ Sample } & \multicolumn{4}{|c|}{ Textile and Apparel Manufacturers (1995-2007) } \\
\hline & (a) & (b) & $(\mathrm{c})$ & (d) \\
\hline Variable & Log Turnover & Log Value Added & Log FTE & Log Labor \\
\hline \multirow[t]{2}{*}{$I M P C H_{i t}$} & $-2.509^{*}$ & $-3.274^{* *}$ & $-3.991^{* *}$ & $-3.271^{* *}$ \\
\hline & $(1.125)$ & $(1.206)$ & $(1.254)$ & $(1.205)$ \\
\hline Year Fixed Effects & yes & yes & yes & yes \\
\hline Firm Fixed Effects & yes & yes & yes & yes \\
\hline $\mathrm{F}$ & 3.269 & 6.539 & 10.109 & 10.440 \\
\hline Number of Obs. & 7274 & 7252 & 7213 & 7319 \\
\hline Number of Firms & 995 & 995 & 992 & 1008 \\
\hline F-test of excluding instr. & 57.569 & 58.227 & 54.876 & 55.671 \\
\hline Hansen J-stat (P-value) & 0.165 & 0.202 & 0.543 & 0.461 \\
\hline First Stage $R^{2}$ & 0.387 & 0.389 & 0.388 & 0.383 \\
\hline \multicolumn{5}{|l|}{ Panel B: Education } \\
\hline & (a) & (b) & (c) & (d) \\
\hline & Employees & Employees & Employees & Employees \\
\hline & with at least & with at most & with T\&C & with $\mathrm{T} \& \mathrm{C}$ \\
\hline Variable & College Educ. & High School Educ. & Production Educ. & Technical Design Educ. \\
\hline \multirow[t]{2}{*}{$I M P C H_{i t}$} & 1.001 & $-4.600^{* * *}$ & $-2.451^{* *}$ & $1.313^{*}$ \\
\hline & $(0.909)$ & $(1.181)$ & $(0.870)$ & $(0.625)$ \\
\hline Year Fixed Effects & yes & yes & yes & yes \\
\hline Firm Fixed Effects & yes & yes & yes & yes \\
\hline $\mathrm{F}$ & 2.352 & 16.214 & 3.424 & 3.156 \\
\hline Number of Obs. & 6893 & 6893 & 6893 & 6893 \\
\hline Number of Firms & 988 & 988 & 988 & 988 \\
\hline F-test of excluding instr. & 80.233 & 80.233 & 80.233 & 80.233 \\
\hline Hansen J-stat (P-value) & 0.086 & 0.426 & 0.070 & 0.130 \\
\hline First Stage $R^{2}$ & 0.391 & 0.391 & 0.391 & 0.391 \\
\hline
\end{tabular}

Results are obtained using 2SLS regressions in which the explanatory variable is the Chinese import share at the firm-level. Robust standard errors are reported in parentheses. They are clustered for firms. IMPCH product portfolio. It is the weighted average of the Chinese import shares in each 8-digit product where the weights are the revenue share of that particular 8-digit product in firms' portfolio in 1999. Instruments that are used for all regressions are $M F A Q R e v S h a r e 99_{i} * D u m 02_{t}$,

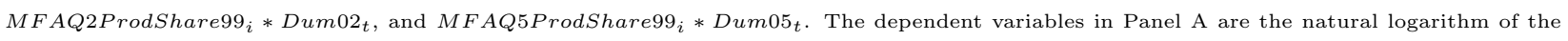
firm turnover (revenue), the natural logarithm of the value-added, the logarithm of the full-time equivalent number of employees and the logarithm of the number of employee head-count respectively in columns (a)-(d). Sales, value-added and FTE information is from Regnskabsdata and headcount information is from IDA, Statistics Denmark. The sample period in Panel A regressions is 1995-2007. The dependent variables in Panel B in columns (a)-(d) are the logarithm of the number of employees with at least some college level education plus 1 , the logarithm of the number of employees with at most high school diploma plus 1, the logarithm of the number of employees with vocational training in textile and clothing production plus 1 and the logarithm of the number of employees with textile and clothing related technical design education plus 1 . The sample period in Panel A regressions is 1995-2006. The source of these data is IDA, Statistics Denmark. 
Table D-8: Two Stage Regressions II

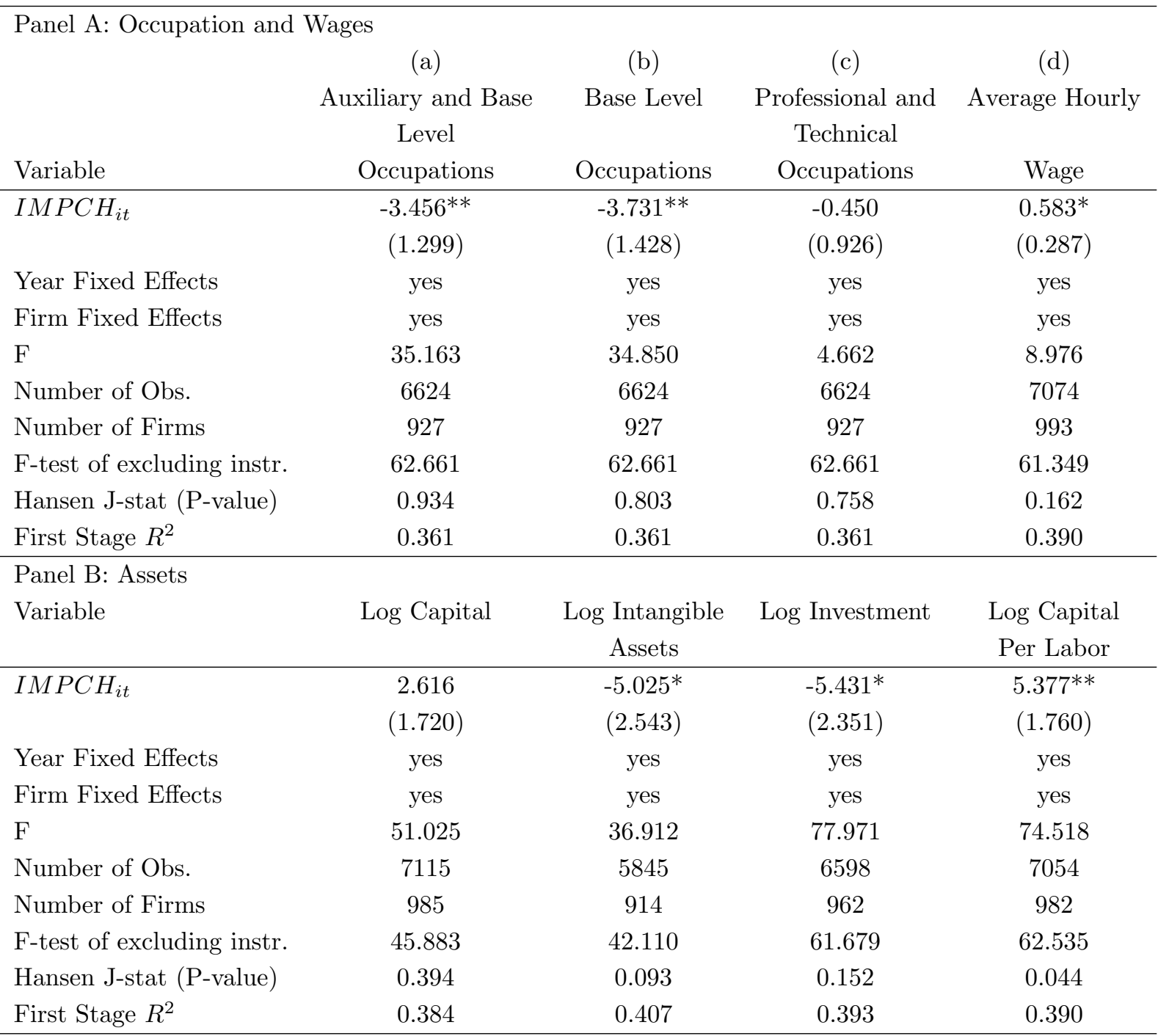

Results are obtained using 2SLS regressions in which the explanatory variable is the Chinese import share at the firm-level. Robust standard errors are reported in parentheses. They are clustered for firms. IMPCH $H_{i t}$ is the firm-specific Chinese import measure based on firms' 1999 product portfolio. It is the weighted average of the Chinese import shares in each 8-digit product where the weights are the revenue share of that particular 8-digit product in firms' portfolio in 1999. Instruments that are used for all regressions except the capital and intangible assets regressions are MFAQRevShare $99_{i} *$ Dum02t, MFAQ2ProdShare $99_{i} *$ Dum $02_{t}$, and

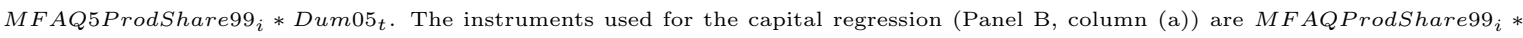

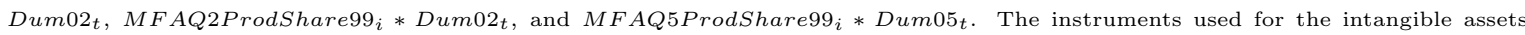

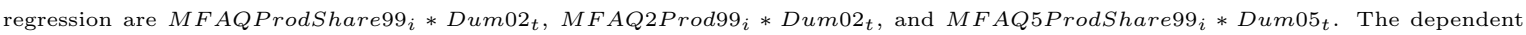
variables in Panel A columns (a)-(d) are the logarithm of the number of employees that are classified as doing basic skill required jobs or no specific skill required jobs plus 1 , the logarithm of the number of employees that are classified as doing basic skill required jobs plus 1 , the logarithm of the number of employees in occupations that are classified as either top-level or intermediate-level plus 1 and the logarithm of the average hourly salary, respectively. The sample period for the occupation variables is 1996-2007 and for the wage variable is 1995-2007. The source of these data is IDA, Statistics Denmark. The dependent variables in Panel B columns (a)-(d) are the logarithms of the tangible assets, intangible assets, investment and the capital-labor ratio respectively. The sample period in Panel $\mathrm{B}$ regressions is 1995-2007. The source of these data is Regnskabsdata, Statistics Denmark. 


\section{D-V Additional Firm-level Controls}

Table D-9: Additional Firm-level Control: Firm Age

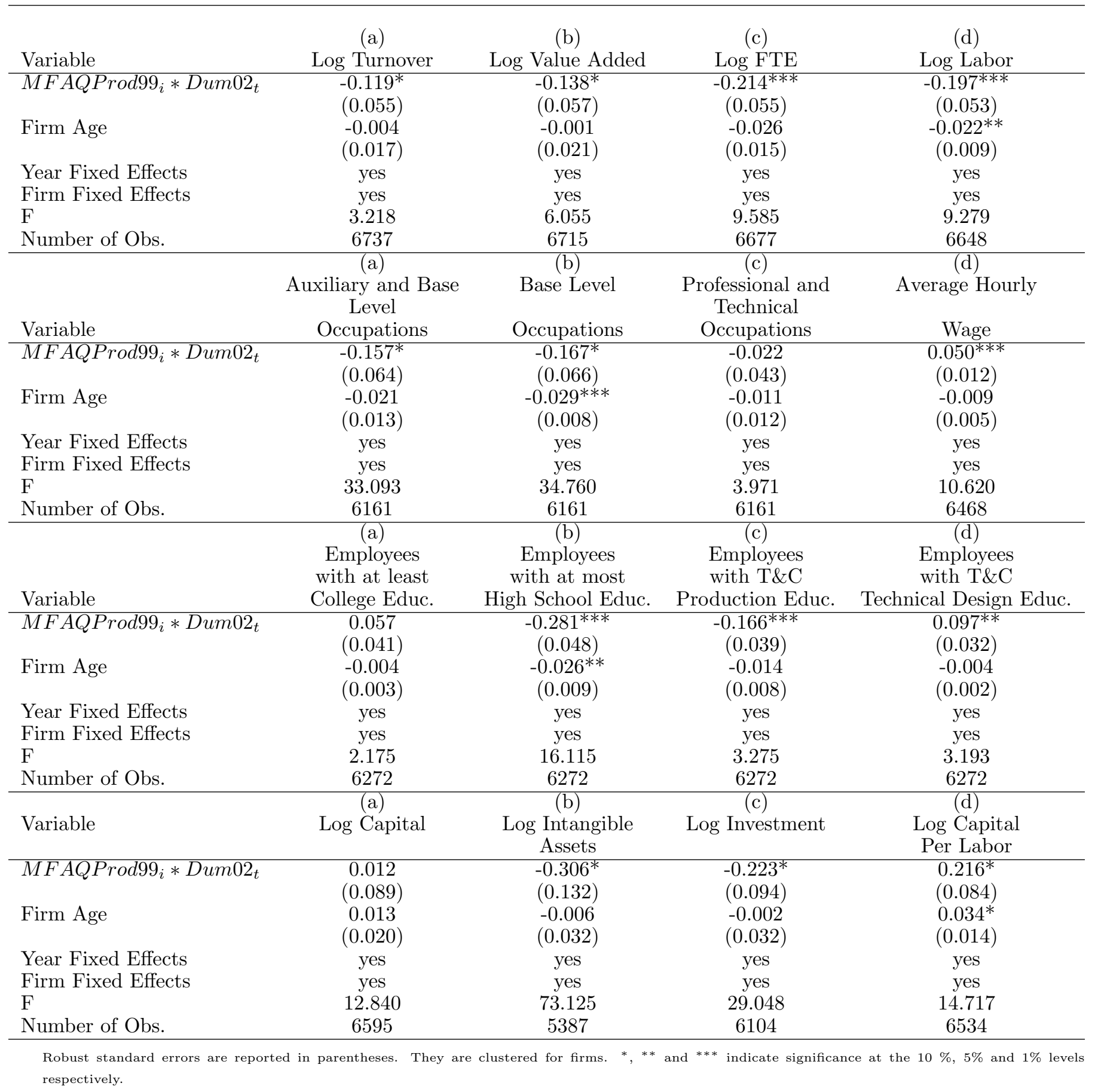


Table D-10: Additional Firm Level Controls: Firm Age, Entry and Exit

\begin{tabular}{|c|c|c|c|c|}
\hline Variable & $\begin{array}{c}\text { (a) } \\
\text { Log Turnover }\end{array}$ & $\begin{array}{c}(\mathrm{b}) \\
\text { Log Value Added }\end{array}$ & $\begin{array}{c}(\mathrm{c}) \\
\log \text { FTE }\end{array}$ & $\begin{array}{c}(\mathrm{d}) \\
\log \text { Labor }\end{array}$ \\
\hline$M F A Q P \operatorname{Prod} 99_{i} * D u m 02_{t}$ & $\begin{array}{l}-0.087 \\
(0.049)\end{array}$ & $\begin{array}{c}-0.109^{*} \\
(0.051)\end{array}$ & $\begin{array}{c}-0.186^{* * *} \\
(0.048)\end{array}$ & $\begin{array}{c}-0.179^{* * *} \\
(0.048)\end{array}$ \\
\hline Firm Age & $\begin{array}{l}-0.021 \\
(0.016)\end{array}$ & $\begin{array}{l}-0.018 \\
(0.019)\end{array}$ & $\begin{array}{c}-0.045^{* *} \\
(0.015)\end{array}$ & $\begin{array}{c}-0.032^{* *} \\
(0.010)\end{array}$ \\
\hline Entry Dummy & $\begin{array}{c}-0.396^{* * *} \\
(0.052)\end{array}$ & $\begin{array}{c}-0.420 * * * \\
(0.050)\end{array}$ & $\begin{array}{c}-0.446^{* * *} \\
(0.046)\end{array}$ & $\begin{array}{c}-0.247^{* * *} \\
(0.042)\end{array}$ \\
\hline Exit Dummy & $\begin{array}{c}-0.416^{* * *} \\
(0.056)\end{array}$ & $\begin{array}{c}-0.484^{* * *} \\
(0.061)\end{array}$ & $\begin{array}{c}-0.493^{* * *} \\
(0.050)\end{array}$ & $\begin{array}{c}-0.576^{* * *} \\
(0.056)\end{array}$ \\
\hline Year Fixed Effects & yes & yes & yes & yes \\
\hline Firm Fixed Effects & yes & yes & yes & yes \\
\hline $\mathrm{F}$ & 11.364 & 14.628 & 24.078 & 17.923 \\
\hline Number of Obs. & 5848 & 5830 & 5798 & 5785 \\
\hline Variable & $\begin{array}{c}\text { (a) } \\
\text { Auxiliary and Base } \\
\text { Level } \\
\text { Occupations }\end{array}$ & $\begin{array}{c}\text { Base Level } \\
\text { Occupations }\end{array}$ & $\begin{array}{c}(\mathrm{c}) \\
\text { Professional and } \\
\text { Technical } \\
\text { Occupations }\end{array}$ & $\begin{array}{c}\text { (d) } \\
\text { Average Hourly } \\
\text { Wage }\end{array}$ \\
\hline$M F A Q P \operatorname{Prod} 99_{i} * \operatorname{Dum} 02_{t}$ & $\begin{array}{c}-0.141^{*} \\
(0.061)\end{array}$ & $\begin{array}{c}-0.148^{*} \\
(0.063)\end{array}$ & $\begin{array}{l}-0.022 \\
(0.042)\end{array}$ & $\begin{array}{c}0.044^{* * *} \\
(0.012)\end{array}$ \\
\hline Firm Age & $\begin{array}{l}-0.026 \\
(0.014)\end{array}$ & $\begin{array}{c}-0.033^{* * *} \\
(0.008)\end{array}$ & $\begin{array}{l}-0.014 \\
(0.012)\end{array}$ & $\begin{array}{l}-0.009 \\
(0.005)\end{array}$ \\
\hline Entry Dummy & $\begin{array}{c}-0.093^{*} \\
(0.042)\end{array}$ & $\begin{array}{c}-0.098^{*} \\
(0.042)\end{array}$ & $\begin{array}{c}-0.068^{* *} \\
(0.026)\end{array}$ & $\begin{array}{c}0.013 \\
(0.014)\end{array}$ \\
\hline Exit Dummy & $\begin{array}{c}-0.405^{* * *} \\
(0.050)\end{array}$ & $\begin{array}{c}-0.411^{* * *} \\
(0.049)\end{array}$ & $\begin{array}{c}-0.162^{* * *} \\
(0.033)\end{array}$ & $\begin{array}{c}0.015 \\
(0.020)\end{array}$ \\
\hline Year Fixed Effects & yes & yes & yes & yes \\
\hline Firm Fixed Effects & yes & yes & yes & yes \\
\hline $\mathrm{F}$ & 37.356 & 39.647 & 5.324 & 8.397 \\
\hline Number of Obs. & 5785 & 5785 & 5785 & 5633 \\
\hline
\end{tabular}


Table D-11: Additional Firm Level Controls: Firm Age, Entry and Exit

\begin{tabular}{|c|c|c|c|c|}
\hline Variable & $\begin{array}{l}\text { (a) } \\
\text { Employees } \\
\text { with at least } \\
\text { College Educ. }\end{array}$ & $\begin{array}{c}\text { (b) } \\
\text { Employees } \\
\text { with at most } \\
\text { High School Educ. }\end{array}$ & $\begin{array}{c}(\mathrm{c}) \\
\text { Employees } \\
\text { with T\&C } \\
\text { Production Educ. }\end{array}$ & $\begin{array}{c}(\mathrm{d}) \\
\text { Employees } \\
\text { with T\&C } \\
\text { Technical Design Educ. }\end{array}$ \\
\hline$M F A Q P r o d 99_{i} *$ Dum $02_{t}$ & $\begin{array}{c}0.045 \\
(0.039)\end{array}$ & $\begin{array}{c}-0.265^{* * *} \\
(0.045)\end{array}$ & $\begin{array}{c}-0.165^{* * *} \\
(0.037)\end{array}$ & $\begin{array}{l}0.077^{*} \\
(0.031)\end{array}$ \\
\hline Firm Age & $\begin{array}{c}-0.008 * * * \\
(0.002)\end{array}$ & $\begin{array}{c}-0.033^{* * *} \\
(0.009)\end{array}$ & $\begin{array}{r}-0.016^{*} \\
(0.008)\end{array}$ & $\begin{array}{r}-0.005^{*} \\
(0.002)\end{array}$ \\
\hline Enter Dummy & $\begin{array}{c}-0.068^{* * *} * \\
(0.020)\end{array}$ & $\begin{array}{c}-0.159^{* * *} \\
(0.036)\end{array}$ & $\begin{array}{l}-0.041 \\
(0.022)\end{array}$ & $\begin{array}{l}-0.011 \\
(0.011)\end{array}$ \\
\hline Exit Dummy & $\begin{array}{c}-0.178^{* * *} \\
(0.032)\end{array}$ & $\begin{array}{c}-0.414^{* * *} \\
(0.045)\end{array}$ & $\begin{array}{c}-0.110^{* * *} \\
(0.024)\end{array}$ & $\begin{array}{c}-0.081^{* * *} \\
(0.019)\end{array}$ \\
\hline Year Fixed Effects & yes & yes & yes & yes \\
\hline Firm Fixed Effects & yes & yes & yes & yes \\
\hline $\mathrm{F}$ & 5.037 & 21.923 & 5.074 & 3.575 \\
\hline Number of Obs. & 5785 & 5785 & 5785 & 5785 \\
\hline Variable & $\begin{array}{c}\text { (a) } \\
\text { Log Capital }\end{array}$ & $\begin{array}{c}\text { (b) } \\
\text { Log Intangible } \\
\text { Assets }\end{array}$ & $\begin{array}{c}(\mathrm{c}) \\
\text { Log Investment }\end{array}$ & $\begin{array}{l}(\mathrm{d}) \\
\text { Log Capital } \\
\text { Per Labor }\end{array}$ \\
\hline$M F A Q P r o d 99_{i} *$ Dum $02_{t}$ & $\begin{array}{l}-0.014 \\
(0.085)\end{array}$ & $\begin{array}{l}-0.231 \\
(0.130)\end{array}$ & $\begin{array}{l}-0.133 \\
(0.093)\end{array}$ & $\begin{array}{l}0.157^{*} \\
(0.078)\end{array}$ \\
\hline Firm Age & $\begin{array}{c}0.011 \\
(0.020)\end{array}$ & $\begin{array}{l}-0.009 \\
(0.031)\end{array}$ & $\begin{array}{l}-0.009 \\
(0.031)\end{array}$ & $\begin{array}{c}0.057^{* *} \\
(0.017)\end{array}$ \\
\hline Enter Dummy & $\begin{array}{l}-0.006 \\
(0.082)\end{array}$ & $\begin{array}{l}-0.097 \\
(0.092)\end{array}$ & $\begin{array}{l}-0.155 \\
(0.091)\end{array}$ & $\begin{array}{c}0.517^{* * * *} \\
(0.076)\end{array}$ \\
\hline Exit Dummy & $\begin{array}{c}-0.317^{* * *} \\
(0.090)\end{array}$ & $\begin{array}{c}-0.365^{* * *} \\
(0.104)\end{array}$ & $\begin{array}{c}-0.382^{* * *} \\
(0.115)\end{array}$ & $\begin{array}{l}0.230^{* *} \\
(0.085)\end{array}$ \\
\hline Year Fixed Effects & yes & yes & yes & yes \\
\hline Firm Fixed Effects & yes & yes & yes & yes \\
\hline F & 13.159 & 70.615 & 26.812 & 15.809 \\
\hline Number of Obs. & 5729 & 4658 & 5364 & 5678 \\
\hline
\end{tabular}




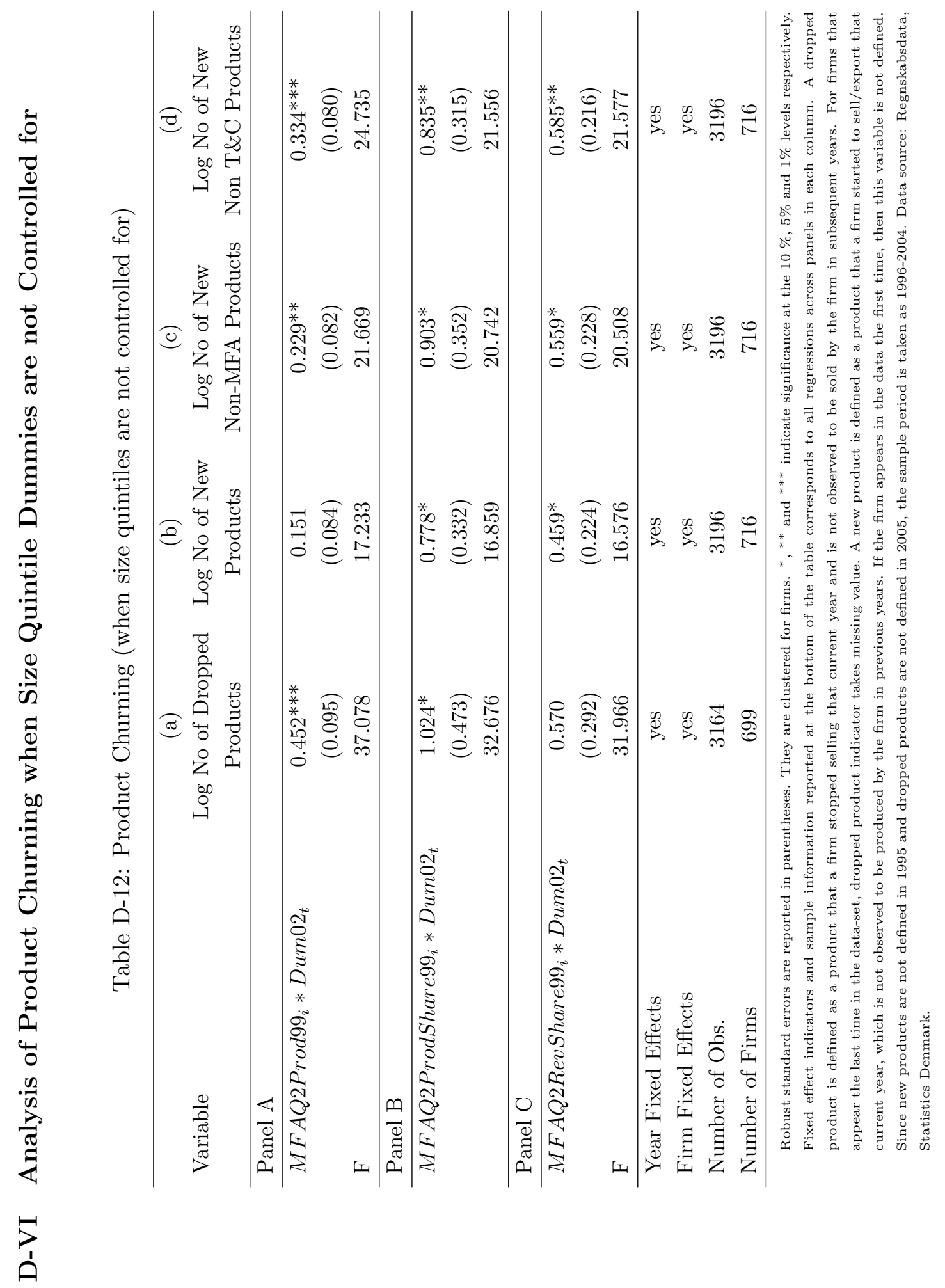




\section{D-VII Analysis of Profit}

Table D-13: Analysis of Profit

\begin{tabular}{|c|c|c|}
\hline Dependent Variable & $\begin{array}{l}\text { Profit } \\
\text { (a) }\end{array}$ & $\begin{array}{l}\text { Profit Dummy } \\
\text { (b) }\end{array}$ \\
\hline \multicolumn{3}{|l|}{ Panel A } \\
\hline$M F A Q P r o d 99_{i} *$ Dum $02_{t}$ & $\begin{array}{l}-0.024 \\
(0.104)\end{array}$ & $\begin{array}{r}-0.063^{*} \\
(0.028)\end{array}$ \\
\hline $\mathrm{F}$ & 3.176 & 2.659 \\
\hline \multicolumn{3}{|l|}{ Panel B } \\
\hline MF AQProdShare $99_{i} *$ Dum $02_{t}$ & $\begin{array}{l}-0.175 \\
(0.159)\end{array}$ & $\begin{array}{c}-0.121^{* *} \\
(0.046)\end{array}$ \\
\hline $\mathrm{F}$ & 3.273 & 2.878 \\
\hline \multicolumn{3}{|l|}{ Panel C } \\
\hline MFAQRevShare $99_{i} *$ Dum $02_{t}$ & $\begin{array}{l}-0.198 \\
(0.145)\end{array}$ & $\begin{array}{c}-0.121^{* *} \\
(0.040)\end{array}$ \\
\hline $\mathrm{F}$ & 3.334 & 3.161 \\
\hline Year Fixed Effects & yes & yes \\
\hline Firm Fixed Effects & yes & yes \\
\hline Number of Obs. & 5843 & 7259 \\
\hline \multicolumn{3}{|c|}{$\begin{array}{l}\text { Robust standard errors are reported in parentheses. They are clustered for firms. } \\
*^{*},{ }^{* *} \text { and }{ }^{* * *} \text { indicate significance at the } 10 \%, 5 \% \text { and } 1 \% \text { levels respectively. } \\
\text { Fixed effect indicators and sample information reported at the bottom of the } \\
\text { table corresponds to all regressions across panels in each column. The dependent } \\
\text { variable in column (a) is the logarithm of profit. The dependent variable in } \\
\text { column (b) is a profit dummy that takes } 1 \text { if profit is positive and zero otherwise. }\end{array}$} \\
\hline
\end{tabular}

Table D-14: Probit Analysis of Profit

\begin{tabular}{|c|c|c|c|}
\hline Dependent Variable & $\begin{array}{l}\text { Profit Dummy } \\
\text { (a) }\end{array}$ & $\begin{array}{l}\text { Profit Dummy } \\
\text { (b) }\end{array}$ & $\begin{array}{l}\text { Profit Dummy } \\
\text { (c) }\end{array}$ \\
\hline MFAQProd $99_{i} *$ Dum $02_{t}$ & $\begin{array}{r}-0.162^{*} \\
(0.077)\end{array}$ & & \\
\hline MFAQProd $99_{i}$ & $\begin{array}{l}-0.058 \\
(0.053)\end{array}$ & & \\
\hline MF AQProdShare $99_{i} *{\text { Dum } 02_{t}}_{t}$ & & $\begin{array}{l}-0.295^{*} \\
(0.142)\end{array}$ & \\
\hline MFAQProdShare $99_{i}$ & & $\begin{array}{c}0.005 \\
(0.092)\end{array}$ & \\
\hline MF AQRevShare $99_{i} *$ Dum $02_{t}$ & & & $\begin{array}{l}-0.313^{*} \\
(0.126)\end{array}$ \\
\hline MFAQRevShare $99_{i}$ & & & $\begin{array}{c}0.095 \\
(0.082)\end{array}$ \\
\hline Firm Level Controls & yes & yes & yes \\
\hline Year Fixed Effects & yes & yes & yes \\
\hline Industry Dummy (Textile/Clothing) & yes & yes & yes \\
\hline$\chi^{2}$ & 96.920 & 91.972 & 91.887 \\
\hline Number of Obs. & 7196 & 7196 & 7196 \\
\hline
\end{tabular}




\section{D-VIII Analysis of Firm Exit}

Table D-15: Probit Analysis of Exit

\begin{tabular}{lc}
\hline Dependent Variable & $\begin{array}{c}\text { Exit Dummy } \\
(\mathrm{a})\end{array}$ \\
\hline MFAQProd $99_{i} *$ Dum02 & 0.048 \\
& $(0.131)$ \\
MF AQProd $99_{i}$ & 0.130 \\
& $(0.104)$ \\
lnTotalAsset & $-0.162^{* * *}$ \\
& $(0.025)$ \\
SinglePlant Dummy & $-0.285^{* *}$ \\
& $(0.107)$ \\
FirmAge & $0.006^{*}$ \\
& $(0.002)$ \\
Year Fixed Effects & yes \\
Industry Dummy (Textile/Clothing) & yes \\
$\chi^{2}$ & 130.096 \\
Number of Obs. & 5796 \\
\hline Robust standard errors are reported in parentheses. & The dependent \\
variable is an exit dummy that takes 1 if a firm exits in the following \\
year and zero otherwise. It is not defined in 2007. The sample period \\
is 1995-2006. Source: Statistics Denmark.
\end{tabular}

\section{References}

[1] Bunzel, Henning (2008), "The LMDG Data Sets", mimeo, Univeristy of Aarhus. 